DR. MARIA APARICIO (Orcid ID : 0000-0002-1604-7562)

Article type : Review Article

\title{
Paediatricians provide higher quality care to children and adolescents in primary care: a systematic review
}

SHORT TITLE: Caring for children in primary care

\section{AUTHORS:}

Aparicio Rodrigo, María. MD, PhD. Associate Professor of Paediatrics. Complutense University of Madrid. Primary paediatrician. Madrid Health Service. Madrid. Spain

Ruiz Canela, Juan. MD. Primary care paediatrician. Andalucía Health Service. Sevilla. Spain

Buñuel Álvarez, Jose Cristóbal. MD. Primary care paediatrician. Aragon Health Service.

Zaragoza. Spain

García Vera, César. MD. Primary care paediatrician. Aragon Health Service. Zaragoza. Spain

Esparza Olcina, Maria Jesús. MD. Primary care paediatrician. Madrid Health Service. Madrid. Spain

Barroso Espadero, Domingo. MD. Primary care paediatrician. Extremadura Health Service. Cáceres. Spain

González Rodríguez, Paz. MD. Primary care paediatrician. Madrid Health Service. Madrid. Spain Juanes Toledo, Blanca. MD. Primary care paediatrician. Madrid Health Service. Madrid. Spain Martínez Rubio, Victoria. MD. Primary care paediatrician. Madrid Health Service. Madrid. Spain Ortega Páez, Eduardo. MD. Primary care paediatrician. Andalucía Health Service. Granada. Spain

This article has been accepted for publication and undergone full peer review but has not been through the copyediting, typesetting, pagination and proofreading process, which may lead to differences between this version and the Version of Record. Please cite this article as doi: 10.1111/APA.15324

This article is protected by copyright. All rights reserved 
Correspondence author: María Aparicio Rodrigo, Centro de Salud Entrevías, C/ Pedroches 3, 28053 Madrid, Spain.

Telephone. No +(34) 699752787

Email:marapa04@ucm.es 


\section{ABSTRACT}

Paediatricians provide higher quality care to children and adolescents in primary care: a systematic review

Aim: The number of primary care paediatricians is decreasing in Europe without a justifiable reason. We aimed to compare the clinical practice of paediatricians and family doctors attending children and adolescents in primary care

Methods: MEDLINE, EMBASE, CENTRAL, TRIP and Google Scholar were searched from $12 / 2008$ to $2 / 2018$. No language or study design restrictions were applied. Three reviewers assessed eligibility of the studies. Seven pairs of reviewers performed the data extraction and assessed the methodological quality independently. Discrepancies were resolved by consensus.

Results: 54, out of 1150 studies preselected, were included. We found that paediatricians show more appropriate pharmacology prescription patterns for the illness being treated; achieve higher vaccination rates and have better knowledge of vaccines and fewer doubts about vaccine safety; their knowledge and implementation of different screening tests are better; prescribe psychoactive drugs more cautiously and more in line with current practice guidelines; their evaluation and treatment of obesity and lipid disorders follow criteria more consistently with current clinical practice guidelines; perform fewer diagnostic test, show a more suitable use of the test and request fewer referrals to specialists.

Conclusion: according to published data, in developed countries, paediatricians provide higher quality care to children than family doctors.

Key words: ambulatory care, family practice, paediatricians, physicians, family, primary healthcare.

Word count: 200

This article is protected by copyright. All rights reserved 


\section{KEY NOTES}

- The number of primary care paediatricians is decreasing in Europe without a clear response from the health authorities

-Paediatricians, irrespective of their place of work or the type of research study in question, are more effective than family doctors at addressing problems related to children in primary care

-A shift from a system of paediatricians to family doctors may lead to a decline in the quality of medical care provided to children

\section{List of abbreviations}

Odds ratio (OR)

95\% confidence intervals $(95 \% \mathrm{Cl})$ 


\section{INTRODUCTION}

For a number of years some European countries have been questioning which medical professional should care for children in primary care (1). Health authorities often consider children and adolescents to be an essentially healthy part of the population. And they are typically not a priority for health policy.

According to recent data (2), the number of paediatricians in Europe has been falling. This study shows that, in primary care, family doctors are replacing paediatricians. The fall in the number of paediatricians in Europe is not a surprise, having already been identified by Van Esso (3) in 2010 and Katz (4) in 1999.

Children's medical attention has been left in the hands of professionals with an average paediatric training of four months (3), with shorter periods or even no formal training in some countries. It has been justified for political and, or economic reasons although many indicators demonstrate that it results in worse outcomes $(5,6)$.

In 2011 the Primary Care Spanish Paediatric Association, aware of the need to gather data highlighting the work of paediatricians in primary care, asked the Group of Evidence-based Paediatrics to carry out a systematic review comparing the work of paediatricians in primary care with that of other professionals. The findings (7) showed that paediatricians prescribed fewer antibiotics for viral infections; were more likely to adhere to clinical practice guidelines in cases of fever and attention deficit hyperactivity disorder; dealt more effectively with other common childhood illnesses (like asthma or otitis media); and achieved higher vaccination rates. The Primary Care Spanish Paediatric Association considered an update to the 2011 systematic review to be necessary.

\section{MATERIAL AND METHODS}

\section{Eligibility criteria}

Studies of any type of design were considered if they compared the clinical practice of paediatricians and family doctors, excluding letters to the editor or editorials. The participants were paediatricians and family doctors who attend children in primary care or hospital emergency departments.

\section{Search strategy}


We searched MEDLINE, EMBASE, Cochrane Central Register of Controlled Trials (CENTRAL), TRIP Database and Google Scholar from December 2008 to February 2018. There was no publication language nor any other restriction applied. Table S1 shows the descriptors used. The Spanish equivalents to the search terms were also used to retrieve additional publications in Google Scholar. We reviewed the references to obtain additional relevant articles.

\section{Data extraction and evaluation of methodological quality}

Three reviewers (JCB, JRC,MAR) independently assessed eligibility of the studies identified by examining titles and abstracts. For those eligible studies, the full paper was obtained.

Disagreements on eligibility were resolved by consensus. The selection process is shown in Figure 1. The selected studies were distributed to seven pairs or reviewers. Each of the reviewers independently extracted the data and assessed the methodological quality with the tool "OSTEBA; Critical Appraisal Cards" (OSTEBA, Basque Office for Health Technology Assessment, Bilbao, Spain).This program evaluates according to three quality levels: low, medium and high, with the evaluation based on six items: clearly defined research question, appropriate methodology, results description, conclusions taking into account the limitations of the study, conflicts of interests and external validity. Any disagreement was resolved by consensus. If this was not possible three of the authors( JCB, JRC,MAR) made the final decision.

\section{Statistical analysis}

Whenever possible Odds ratio $(\mathrm{OR})$ for cohort studies and Prevalence ratio in cross sectional studies were calculated, if not provided, with $95 \%$ confidence intervals $(95 \% \mathrm{Cl})$.

Results of the studies were combined when possible with a global combined estimator (OR), using the inverse variance method, and applying either a fixed effects model, or a random effects model, depending on the presence or not of statistical heterogeneity (estimated with Cochrane's $\mathrm{Q}$ test; and with 12). Publication bias was evaluated by the Begg method.

\section{RESULTS}

We included 54 studies : one before-and-after study, 15 cohort studies and 38 cross-sectional studies.

\section{Antibiotic use in respiratory tract infections}

We included eight retrospective cohort studies (Table 1). Heterogeneity did not allow a metaanalysis to be performed. In five articles (8-12) antibiotic prescription was more appropriate by 
paediatricians. In two of them $(13,14)$ there were no differences. In the final study, family doctors made better prescriptions (15).

\section{Otitis media management}

We included three studies: one cross-sectional survey (16) and two cohort studies (17,-18) (Table 2). All the studies found that paediatricians' prescription for acute otitis media adhere better to guidelines than family doctors' did.

\section{Asthma management}

We included three studies: two cross-sectional studies $(19,20)$ and one retrospective cohort study (21) (Table 3). In all but one (21) family doctors got better results.

\section{Management of psychiatric disorders}

We selected two studies (Table 4): one cross-sectional study (22) which evaluated the specific skills for the management of psychiatric conditions among primary care professionals in a setting with a lack of specialists in psychiatry. Paediatricians and family doctors performed similarly. The other one (23) was a retrospective cohort study designed to investigate a previously discovered increase of prescription rates of psychotropic drugs in patients younger than 18 years of age. In this case, paediatricians performed more in accordance with guidelines than did family doctors.

\section{Immunizations}

We selected 19 papers: 18 cross-sectional studies and one cohorts study (Table 5). Six of the studies considered the human papillomavirus vaccine (24-29) and all were based in the USA. In four, paediatricians did better than family doctors did. In two of them there were no differences. Two cross-sectional studies analysed the attitudes towards the flu vaccine $(30,31)$ in at-risk children. One found better results for paediatricians in children with asthma. The other found no differences. A further paper (32) studied the attitude towards vaccines of paediatricians and family doctors.

Paediatricians recommended all vaccinations more frequently. In two cross-sectional studies $(33,34)$ analysing practices related to rotavirus vaccine in the USA, paediatricians did better than family doctors did. Kempe et al (35) analysed in 2010 the compliance of the regulations on type $B$ Haemophilus Influenzae vaccination in the USA in shortage periods. Paediatricians were more often familiar with the recommendations in these circumstances. Tolaymat et al (36)studied the knowledge of vaccination guidelines for children with inflammatory bowel illness and 
immunosuppressant treatment. Paediatricians more frequently identified vaccines that should not be given to these patients.

The studies on vaccination in Europe relating to MMV, pertussis and pneumococcal vaccines (37); hepatitis B vaccine (38) and meningitis B vaccine (39), favoured paediatricians.

Two studies $(40,41)$, analysing the influence of the specialty of the physician on vaccination refusal in the USA, found mixed results.

Finally, one study (42) analysing the completion of vaccination charts in 2017 found that paediatricians did better than family doctors.

\section{Cardiovascular risk}

The attitude of paediatricians and family doctors towards cardiovascular risk in childhood, was evaluated in five studies (diagnosis and prevention of overweight and obesity [43-45], sudden cardiac death screening in athletes [46], lipid alteration [47]). Four showed results in favour of paediatricians and one found similar results in paediatricians and family doctors (Table 6).

\section{Other preventive activities}

The provision of preventive healthcare services, other than vaccination, was assessed in eight studies (48-55). All of them were cross-sectional studies of low quality. In all but one the results favoured paediatricians (Table7).

\section{Diagnostic tests}

We found five studies performing comparison in this field (56-60). One was a retrospective cohort study; the other four were cross-sectional studies (Table 8). Paediatricians showed better results than family doctors in all of them.

\section{DISCUSSION}

The results of this review show that paediatricians, irrespective of their place of work or the type of research study in question, are more effective than family doctors at addressing problems related to children in primary care. Our findings are consistent with those studies published prior to 2008 and summarized in the previous systematic review (7).

Recent studies on antibiotic treatment have been included in this review. These showed that, except in a few specific cases, paediatricians more frequently prescribe antibiotics in line with clinical practice guidelines and more appropriate for child infectious diseases than family doctors do. Only one study (15) found that family doctors' prescription of antibiotics was better than that 
of paediatricians. This study was carried out in one paediatrician's office, who attended 530 children, and compared with seven family doctors' practices, who were also university professors and who covered 436 children in total. The age ranges treated by each professional were not specified. The authors of the study noted that their findings might not be representative, given the high level of expertise of the university professors. This specific study noted that the paediatricians referred four to five times more children to specialists and hospitals in comparison to the family doctors. Two other studies found no differences in the prescription of antibiotics. Overall, the data are similar to the previous systematic review (7), where the meta-analysis showed a 1 to 1.8 times greater likelihood of primary care non-paediatric doctors, prescribing antibiotics for respiratory tract infections of likely viral aetiology when compared with paediatricians .

These findings are more significant than they might appear. Incorrect use of antibiotics, frequently due to prescriptions for viral infections, exponentially increases the risk of bacterial resistance, iatrogenic harm and cost.

There were only three new studies on the treatment of otitis media. All three showed more appropriate antibiotics prescribing practices by paediatricians. The previous systematic review (7) covered a higher number of publications on this subject (12 in total). Seven of these analysed the adherence to clinical practice guidelines or expert consensus. All of the studies except one found that paediatricians adhered more frequently to clinical practice guidelines. The five other studies compared clinical practices without using a standard for comparison. Except for a casecontrol study, of medium quality, which found no differences between paediatricians and family doctors when analysing diagnostic certainty for otitis with tympanocentesis, all the other studies found better antibiotics prescribing practices by paediatricians and a higher number of referrals to the otolaryngology specialists by family doctors.

Three studies on asthma were considered. One of them found that family doctors were more sensitive to economic factors. Another one found a higher use of spirometry by family doctors. The third analysed the treatment of childhood asthma and found a higher use of short-term oral corticosteroids treatment (following the current guidelines) by paediatricians, although this practice was not linked to lower levels of hospitalization. There were no data to assess the adequacy of the practice in this particular study, which was an analysis of a medical database. In the previous systematic review (7) aspects that have not been addressed again in this update were analysed: prescription of antibiotics for asthma, which was higher among family doctors, and other drugs prescribed for asthma, which was similar between paediatricians and family 
doctors. Also included a cross-sectional study carried out in the USA which found that family doctors used spirometry more frequently (whereas paediatricians used peak-flow meters more often), in line with our results.

The present review covered two articles on the treatment of psychiatric illness. One of these studies (22) found that paediatricians were more confident managing attention deficit hyperactivity disorder whereas family doctors felt more confident with anxiety and depression. However, the response rates were very low. The authors themselves cast doubt on whether the results were representative while other factors were not controlled, like the use of psychotherapy. The second study (23), analysed the prescribing of antipsychotic drugs and found an increase among older children (12-18 years old) when treated by family doctors and psychiatrists, mainly using second generation antipsychotic drugs and against the recommendations of clinical practice guidelines. The study did not specify the number of children according to age treated by each professional or other details that would have allowed us to carry out a more detailed analysis of this prescribing practice. The previous systematic review (7) covered three crosssectional studies carried out by the same authors. Two of these analysed the adherence to clinical practice guidelines on hyperactivity disorder of the American Academy of Pediatrics and found better results for paediatricians. In the third study, the authors assessed prescribing of antipsychotics in primary care settings in the USA. They found that family doctors had a higher probability of prescribing selective serotonin re-uptake inhibitors, irrespective of the diagnosis, which coincides with our findings.

The largest number of articles covered by this systematic review relate to vaccination. Six of the articles covered the human papillomavirus vaccination. Most of the studies (four out of six), including the only cohort study, found that paediatricians recommended the human papillomavirus vaccination more often and achived better vaccination coverages. The cohort study found that paediatricians obtained 1.5 times higher rate of vaccinations than family doctors. Only two studies, and with much lower response rates (41\%), found no differences between paediatricians and family doctors.

In another study (32) the general attitude towards vaccines was assessed. Paediatricians recommended all vaccines more frequently. The main reason why children were not vaccinated was due to doubts about the safety of vaccines. Two other studies on the rotavirus vaccine found that paediatricians recommended the vaccine more frequently, had a better understanding of it and fewer doubts about its safety. 
Paediatricians typically have a more extensive knowledge of vaccines regulation, as shown in the studies on Haemophilus Influenzae vaccination during a period of vaccine shortage (35), or on the vaccination of children receiving immunosuppressive therapy (36).

Only three of the 19 studies on vaccinations were carried out in Europe (France); the rest were undertaken in the USA. The results, however, were consistent. The French studies found a stricter adherence to immunization schedules by paediatricians, who also recommended vaccines more often, vaccinated more and were more knowledgeable on vaccines.

There were only two studies that analysed the rejection of vaccination. They compared the requests for signed authorization forms - a practice recommended by some guidelines - that were higher among paediatricians, and the exclusion from medical practices of those families which refuse vaccination. This practice is not recommended by paediatric associations and was more common among paediatricians. There was no data on this topic in the previous systematic review (7).

The use of anti-flu vaccinations for high-risk patients was analysed in two studies. One found that paediatricians vaccinated children with intermittent asthma four times more often, and children with severe asthma fourteen times more often than family doctors did. The other study identified no differences between anti-flu vaccination rates of healthy and high-risk children when treated by family doctors or paediatricians.

Another study analysed the use of vaccination records. Family doctors were less aware of vaccination records and used them less.

The findings of this systematic review are aligned with those of the previous one (7), which also covered a high number of studies. Doubts about vaccine safety is of concern as health professionals have the greatest influence on families deciding whether to vaccinate their children (61).

Childhood obesity is currently an important global health issue. The studies covered showed that paediatricians made assessments and recommended treatments of childhood obesity according to clinical practice guidelines. There were no available studies regarding the results of these practices. These findings are in line with those from the previous systematic review (7).

Only one of the studies analysed the attitudes towards lipid disorders. Paediatricians followed clinical practice guidelines more frequently, offering better management and treatment for these disorders, coinciding with the previous systematic review (7).

This article is protected by copyright. All rights reserved 
Paediatricians handle screening programs in a more appropriate way than family doctors, as shown in the selected studies on the management of tests to assess the psychomotor development and neurodevelopmental disorders (paediatricians use them more, interpret them better, produce reports on them more often and make more referrals to early intervention services). Concerning the "new-born screening metabolic test", a study (51) in Canada showed how family doctors acknowledge their lack of training, whereas paediatricians are two to three times more likely to know about it, how to interpret its results and how to inform families. Similarly, paediatricians have more knowledge on other preventive activities, such as oral health programs, understanding of popular games among adolescents-and are more aware of child protection policies. These results are consistent with those of the earlier systematic review (7), which found that, the younger the child, the more likely paediatricians were to carry out preventive activities than were family doctors.

Paediatricians used the streptococcal test more frequently and prescribed fewer antibiotics for acute pharyngitis. Paediatricians were more often aware of the recommendations for the treatment and management of neonatal hyperbilirubinemia. Paediatricians were also more likely to diagnose suspected celiac disease based on gastrointestinal and general symptoms and were more knowledgeable of the diagnosis criteria for bronchiolitis. Similarly, paediatricians made earlier diagnoses of acute lymphoblastic leukaemia. Again, this coincides with the previous systematic review (7), which also found better use of the streptococcal test and other diagnostic tests and fewer requests for them, in general, from paediatricians.

This systematic review had several limitations. Most of the studies have an observational crosssectional design and were carried out through self-completion questionnaires, with a very variable (and sometimes low) number of responses. This can lead to patient selection bias. Others were retrospective cohort studies, whose results were collated from large healthcare databases with limited detailed records, insufficient for a more thorough analysis. Both types of studies are rated as low quality of evidence according to the Grading of Recommendations, Assessment, Development and Evaluation system (GRADE) system. The outcomes selected by the studies have a very different degree of interest. A further limitation was the low rate of responses in some of the articles. The individual quality of the studies was evaluated using the critical assessment forms from the Osteba platform; however, there are no internationally recognized tools to evaluate the quality of cross-sectional studies. In addition, for some of the studies, the comparison between the practice of family doctors and paediatricians was not the focus. Nonetheless, the number of studies is high, and the consistency of their results could compensate (partly) for lack of quality. A meta-analysis was not possibly due to the lack of 
homogeneity among the studies. For the same reason it was also not possible to add new studies to the meta-analysis of the previous systematic review.

In summary, this systematic review shows how paediatricians manage the processes related to child health in a more appropriate way than family doctors, and the results of studies published between 2008 and 2018 are similar to those published before 2008. This suggests that, despite the low quality of the studies, the results are not due to chance, but rather the consequence of better training and preparation on the part of paediatricians for the task of managing child health.

As Van Esso (3) described, in Europe there are three models for the care of infants and children's health: only by paediatricians, by a mixture of paediatricians and family doctors and only by family doctors. Despite the results and conclusions published by Katz in 2002 (4) - which showed that the risk of child mortality is lower when paediatricians in primary care are responsible for treating children outside hospital - Van Esso observes how there is a growing tendency for children to be treated by family doctors. Moreover, this is despite the poor outcomes in child health which have been observed in the UK $(5,6,62,63)$, the country which best represents the model of exclusively family doctors in primary care.

In Europe overall, there is not now clear support for the role of paediatricians in the treatment of children in primary care. This fall in support for paediatricians has a number of causes, as Ehrlich set out in a recent publication (2). Twelve of the 40 countries that participated in the study recognized that they are assessing which specialist is best placed to attend to the paediatric population in primary care: family doctors or paediatricians. The reasons given for the change are economic (nine countries out of 12); political (six of 12); professional standing (four of 12); historical (two of 12) and geographical (one of 12). Notably, none of the countries referred to infant health outcomes.

Governments include economics as a reason for change from a system of paediatricians in primary care to family doctors. There is, however, no study supporting this approach. In this systematic review, despite an active search, we have not found any studies which consider the economic outcomes according to the medical professional responsible for paediatric care. The only data available on this issue are those of the study carried out in the Italian region of Molise (64). The findings were such that had paediatricians treated all of the children, the savings would have been of $€ 6.5 \mathrm{~m}$ in three years. The findings of this study were presented in a conference in Italy but were not published.

Up until now there have been only limited indicators of child health (neonatal mortality rate, the infant mortality rate, the mortality rate for children under five, delayed development, 
malnourishment), and this has made it difficult to quantify other aspects of paediatric care for effective comparisons (as antibiotic prescription, vaccinations or adherence to clinical practice guidelines). Recently the first study of paediatric indicators has been published (65). We hope that these indicators will facilitate these comparisons in the future.

Given the lack of indicators, the quality of paediatric care can be evaluated indirectly by assessing the training of the medical professionals providing it. According to the findings of Ehrlich (2), the duration of the training period for paediatricians in Europe lasts between two and six years with an average of four or five years in the majority of countries. In $50 \%$ of the countries, paediatricians have specific training in paediatrics in primary care. On the other hand, the training in paediatrics of family doctors, according to Van Esso (3), lasts for three to six months with an average of four months. In some countries, such as the UK, there is no particular paediatric training for family doctors.

The shift in primary care for infants and children from a system run by paediatricians to one run by family doctors is not based on any research, whether clinical or economic. The logical conclusion that a better-trained specialist offers better care is supported by the published studies highlighted in this review. This indicates that a shift from a system of paediatricians to family doctors may lead to a decline in the quality of medical care provided to children. Children's health is particularly important because it ensures improved health in adulthood (66); this in return reduces healthcare costs and improves the overall quality of life of the population.

\section{CONCLUSION}

The main conclusion of our review is that, according to published data, in developed countries paediatricians provide higher quality care to children than do family doctors. That is: paediatricians' pharmacology prescription pattern is more appropriate for the illnesses being treated; paediatricians make less frequent inadequate use of medication (both antibiotics and other medication like psychoactive drugs); they achieve higher vaccination rates and have better knowledge of vaccines and less doubts about vaccine safety; their knowledge and implementation of different screening tests is better; they prescribe psychoactive drugs more cautiously and more in line with clinical practice guidelines; their evaluation and treatment of obesity and lipid disorders follows criteria more consistent with current clinical practice guidelines; they make fewer and more suitable use of diagnostic tests and they make fewer referrals to specialists. 
We would like to call upon healthcare authorities to prioritize child health and to set out a strategy to ensure not only adequate replacement of current paediatricians but also sufficient specialist professionals to provide proper paediatric primary care (67).

\section{ACKNOWLEDGEMENTS}

The authors would like to thank Dr Carlos Ochoa, MD, for the methodological advice and Dr.

Pilar Aizpurua Galdeano, Dr. Mercedes Fernández Rodríguez, Dr. Gloria Orejón de Luna, Dr.

Ana Díaz Cirujano, Dr Enrique Rodríguez-Salinas, Dr Pedro Martín Muñoz, Dr Leonidas

Perdikidis Olivieri for data extraction and evaluation of methodological quality

\section{FINANCE}

This study did not receive any specific funding.

\section{CONFLICT OF INTEREST}

The authors have no conflict of interest to declare 


\section{REFERENCES}

1. Ehrich J, Namazova-Baranova L, Pettoello-Mantovani M. Introduction to "Diversity of Child Health Care in Europe: a study of the European Paediatric Association/Union of National European Paediatric Societies and Associations." J Pediatr 2016; 177S:S1-10.

2. Ehrich JHH, Tenore A, del Torso S, Pettoello-Mantovani M, Lenton S, Grossman Z. Diversity of pediatric workforce and education in 2012 in Europe: a need for unifying concepts or accepting enjoyable differences? J Pediatr 2015; 167:471-476.e4.

3. van Esso D, del Torso S, Hadjipanayis A, Biver A, Jaeger-Roman E, Wettergren B, et al. Paediatric primary care in Europe: variation between countries. Arch Dis Child 2010; 95:7915.

4. Katz M, Rubino A, Collier J, Rosen J, Ehrich JHH. Demography of pediatric primary care in Europe: delivery of care and training. Pediatrics 2002; 109:788-96.

5. Horton R. Offline: The UK's child health emergency. Lancet 2018; 392:106.

6. Wolfe I, Thompson M, Gill P, Tamburlini G, Blair M, van den Bruel A, et al. Health services for children in western Europe. Lancet 2013; 381:1224-34.

7. Buñuel Alvarez C, Garcia Vera C, Gonzalez Rodriguez P, Aparicio Rodrigo M, Barroso Espadero D, Cortés Marina R. What medical professional is the most adequate, in developed countries, to provide health care to children in primary care? Systematic review. Rev Pediatría Aten Primaria 2010; 12:s9-72.

8. Clavenna A, Sequi M, Bonati M. Differences in the drug prescriptions to children by Italian paediatricians and general practitioners. Eur J Clin Pharmacol 2010; 66:519-24.

9. Pulcini C, Lions C, Ventelou B, Verger P. Indicators show differences in antibiotic use between general practitioners and paediatricians. Eur J Clin Microbiol Infect Dis 2013; 32:929-35.

10. Sellam A, Chahwakilian P, Cohen R, Béchet S, Vie Le Sage F, Lévy C. [Impact of guidelines on ambulatory pediatric antibiotic prescriptions]. Arch Pediatr 2015; 22:595-601.

11. Watson JR, Wang L, Klima J, Moore-Clingenpeel M, Gleeson S, Kelleher K, et al. Healthcare claims data: an underutilized tool for pediatric outpatient antimicrobial stewardship. Clin Infect Dis $2017 ; 64: 1479-85$.

12. Fleming-Dutra KE, Demirjian A, Bartoces M, Roberts RM, Taylor TH, Hicks LA. Variations in antibiotic and azithromycin prescribing for children by geography and specialty-United States, 2013. Pediatr Infect Dis J 2018; 37:52-8. 
13. Blommaert A, Coenen S, Gielen B, Goossens H, Hens N, Beutels P. Patient and prescriber determinants for the choice between amoxicillin and broader-spectrum antibiotics: a nationwide prescription-level analysis. J Antimicrob Chemother 2013; 68:2383-92.

14. Urkin J, Allenbogen M, Friger M, Vinker S, Reuveni H, Elahayani A. Acute pharyngitis: low adherence to guidelines highlights need for greater flexibility in managing paediatric cases. Acta Paediatr 2013; 102:1075-80.

15. Stojanović-Spehar S, Blazeković-Milaković S, Bergman-Marković B, Vrca-Botica M, Matijasević I. Prescribing antibiotics to preschool children in primary health care in Croatia. Coll Antropol 2008; 32:125-30.

16. Ganga-Zandzou PS, Fermantel A, Robic C, Pouessel G, Pierre M-H, Bourgois B, et al. [Assessment of the management of acute otitis media in children by family practitioners in the North of France]. Presse Med 2009; 38:1730-7.

17. Grossman Z, Silverman BG, Miron D. Physician specialty is associated with adherence to treatment guidelines for acute otitis media in children. Acta Paediatr 2013; 102:e29-33.

18. Shviro-Roseman N, Reuveni H, Gazala E, Leibovitz E. Adherence to acute otitis media treatment guidelines among primary health care providers in Israel. Braz J Infect Dis 2014; 18:355-9.

19. Patel MR, Coffman JM, Tseng C-W, Clark NM, Cabana MD. Physician communication regarding cost when prescribing asthma medication to children. Clin Pediatr (Phila) 2009; 48:493-8.

20. Dombkowski KJ, Hassan F, Wasilevich EA, Clark SJ. Spirometry use among pediatric primary care physicians. Pediatrics 2010; 126:682-7.

21. Farber HJ, Silveira EA, Vicere DR, Kothari VD, Giardino AP. Oral corticosteroid prescribing for children with asthma in a medicaid managed care program. Pediatrics 2017; 139.

22. Fremont WP, Nastasi R, Newman N, Roizen NJ. Comfort level of pediatricians and family medicine physicians diagnosing and treating child and adolescent psychiatric disorders. Int $J$ Psychiatry Med 2008; 38:153-68.

23. Ronsley R, Scott D, Warburton WP, Hamdi RD, Louie DC, Davidson J, et al. A populationbased study of antipsychotic prescription trends in children and adolescents in British Columbia, from 1996 to 2011. Can J Psychiatry 2013; 58:361-9.

24. Daley MF, Crane LA, Markowitz LE, Black SR, Beaty BL, Barrow J, et al. Human papillomavirus vaccination practices: a survey of US physicians 18 months after licensure. Pediatrics 2010; 126:425-33. 
25. Vadaparampil ST, Kahn JA, Salmon D, Lee J-H, Quinn GP, Roetzheim R, et al. Missed clinical opportunities: provider recommendations for HPV vaccination for 11-12 year old girls are limited. Vaccine 2011; 29:8634-41.

26. Kulczycki A, Qu H, Shewchuk R. Primary Care Physicians' Adherence to Guidelines and their likelihood to prescribe the human papillomavirus vaccine for 11- and 12-year-old girls.

Womens Health Issues 2016; 26:34-9.

27. Allison MA, Hurley LP, Markowitz L, Crane LA, Brtnikova M, Beaty BL, et al. Primary care physicians' perspectives about HPV vaccine. Pediatrics 2016; 137:e20152488.

28. Finney Rutten LJ, St Sauver JL, Beebe TJ, Wilson PM, Jacobson DJ, Fan C, et al. Association of both consistency and strength of self-reported clinician recommendation for HPV vaccination and HPV vaccine uptake among 11- to 12-year-old children. Vaccine 2017; 35:6122-8.

29. Wilbur MB, Clarke M, Chou B, Phelan-Emrick D. Variations in HPV vaccination rates of adolescent and young adult females by provider specialty. Ginecologic oncology 2016; 141:2-208.

30. Dombkowski KJ, Leung SW, Clark SJ. Physician perspectives regarding annual influenza vaccination among children with asthma. Ambul Pediatr 2008; 8:294-9.

31. Toback SL, Rothstein E, Bhatt P, Carr W, Ambrose CS. In-office influenza vaccination by US pediatric providers varies greatly and is higher among smaller offices. Clin Pediatr (Phila) 2012; 51:551-9.

32. Gust D, Weber D, Weintraub E, Kennedy A, Soud F, Burns A. Physicians who do and do not recommend children get all vaccinations. J Health Commun 2008; 13:573-82.

33. Kempe A, Patel MM, Daley MF, Crane LA, Beaty B, Stokley S, et al. Adoption of rotavirus vaccination by pediatricians and family medicine physicians in the United States. Pediatrics 2009; 124:e809-816.

34. O'Leary ST, Parashar UD, Crane LA, Allison MA, Stokley S, Beaty BL, et al. Adoption of rotavirus vaccine by U.S. physicians: progress and challenges. Am J Prev Med 2013; 44:5662.

35. Kempe A, Babbel C, Wallace GS, Stokley S, Daley MF, Crane LA, et al. Knowledge of interim recommendations and use of Hib vaccine during vaccine shortages. Pediatrics 2010; 125:914-20.

36. Tolaymat $\mathrm{N}$, Lenhart $\mathrm{C}$. Vaccination practice for pediatric inflammatory disease patients receiving immuno-suppressive therapy. The Am Jour Gastroenterol 2013; 108 supl1:s622. 
37. Pruvost I, Lowingerova-Fauvet S, Debacker P, Dervaux B, Dubos F, Martinot A. [Assessment of primary care physicians' adherence to the national childhood vaccination schedule]. Arch Pediatr 2012; 19:248-53.

38. Vié le Sage F, Gaudelus J, Lert F, Dufour V, Texier N, Pouriel M, et al. Public health impact of Infanrix hexaTM (DTPa-HBV-IPV/Hib) reimbursement: a study programme in France. Part 2: evolution of the acceptability of infants' vaccination against hepatitis $B$ in general and pediatric practices - the PRALINE study. Rev Epidemiol Sante Publique 2016; 64:185-94.

39. Levy C, Bechet S, Cohen R. [Implementation of meningococcal B vaccination (Bexsero®) in France: physicians' perceptions and experiences of a few months after marketing approval]. Arch Pediatr 2016; 23:27-33.

40. Kempe A, Daley MF, McCauley MM, Crane LA, Suh CA, Kennedy AM, et al. Prevalence of parental concerns about childhood vaccines: the experience of primary care physicians. Am J Prev Med 2011; 40:548-55.

41. O'Leary ST, Allison MA, Fisher A, Crane L, Beaty B, Hurley L, et al. Characteristics of physicians who dismiss families for refusing vaccines. Pediatrics 2015; 136:1103-11.

42. Kempe A, Hurley LP, Cardemil CV, Allison MA, Crane LA, Brtnikova M, et al. Use of immunization information systems in primary Care. Am J Prev Med 2017; 52:173-82.

43. He M, Piché L, Clarson CL, Callaghan C, Harris SB. Childhood overweight and obesity management: a national perspective of primary health care providers' views, practices, perceived barriers and needs. Paediatr Child Health 2010; 15:419-26.

44. Huang TT-K, Borowski LA, Liu B, Galuska DA, Ballard-Barbash R, Yanovski SZ, et al. Pediatricians' and family physicians' weight-related care of children in the U.S. Am J Prev Med 2011; 41:24-32.

45. Harkins PJ, Lundgren JD, Spresser CD, Hampl SE. Childhood obesity: survey of physician assessment and treatment practices. Child Obes 2012; 8:155-61.

46. Madsen NL, Drezner JA, Salerno JC. Sudden cardiac death screening in adolescent athletes: an evaluation of compliance with national guidelines. Br J Sports Med 2013; 47:172-7.

47. Dixon DB, Kornblum AP, Steffen LM, Zhou X, Steinberger J. Implementation of lipid screening guidelines in children by primary pediatric providers. J Pediatr 2014; 164:572-6.

48. McClave JL, Russell PJ, Lyren A, O'Riordan MA, Bass NE. The choking game: physician perspectives. Pediatrics 2010; 125:82-7.

49. Herndon JB, Tomar SL, Lossius MN, Catalanotto FA. Preventive oral health care in early childhood: knowledge, confidence, and practices of pediatricians and family physicians in Florida. J Pediatr 2010; 157:1018-1024.e1-2. 
50. Burney M, Schunk K, Oundjian NJ, Younge RG, McCord M, Green NS. Incomplete follow-up of hemoglobinopathy carriers identified by newborn screening despite reporting in electronic medical records. J Natl Med Assoc 2011; 103:852-6.

51. Hayeems RZ, Miller FA, Carroll JC, Little J, Allanson J, Bytautas JP, et al. Primary care role in expanded newborn screening: After the heel prick test. Can Fam Physician 2013; 59:861-8.

52. Vyas KS, Brancato C, Soares NS. WHO growth chart awareness among clinicians in Kentucky. South Med J 2013; 106:495-9.

53. Knutson S, Kelleman MS, Kochilas L. Implementation of developmental screening guidelines for children with congenital heart disease. J Pediatr 2016; 176:135-141.e2.

54. Ayou C, Gauducheau E, Arrieta A, Roussey M, Marichal M, Vabres N, et al. [Child protection: pediatricians' knowledge and practices in Brittany]. Arch Pediatr 2018; 25:207-12.

55. Moore C, Zamora I, Patel Gera M, Williams ME. Developmental screening and referrals: assessing the influence of provider specialty, training, and interagency communication. Clin Pediatr (Phila) 2017; 56:1040-7.

56. Park M, Hue V, Dubos F, Lagrée M, Pruvost I, Martinot A. [Reasons for low usage of strep A rapid antigen detection tests for pharyngitis in private medical practice]. Arch Pediatr 2013; 20:1083-8.

57. Mateo PC, Lee K-S, Barozzino M, Sgro M. Management of neonatal jaundice varies by practitioner type. Can Fam Physician 2013; 59:e379-386.

58. Pham BN, Musset L, Chyderiotis G, Olsson NO, Fabien N. Celiac disease diagnosis: impact of guidelines on medical prescription in France. J Dig Dis 2014; 15:435-43.

59. Lee JM, Eason A, Nelson C, Kazzi NG, Cowan AE, Tarini BA. Screening practices for identifying type 2 diabetes in adolescents. J Adolesc Health 2014; 54:139-43.

60. Gupta S, Gibson P, Pole JD, Sutradhar R, Sung L, Guttmann A. Predictors of diagnostic interval and associations with outcome in acute lymphoblastic leukemia. Pediatr Blood Cancer 2015; 62:957-63.

61. Simone B, Carrillo-Santisteve P, Lopalco PL. Healthcare workers' role in keeping MMR vaccination uptake high in Europe: a review of evidence. Eurosurveillance 2012; 17:20206.

62. Wolfe I, Cass H, Thompson MJ, Craft A, Peile E, Wiegersma PA, et al. Improving child health services in the UK: insights from Europe and their implications for the NHS reforms. BMJ 2011; 342:d1277.

63. Wolfe I, Donkin A, Marmot M, Macfarlane A, Cass H, Viner R. UK child survival in a European context: recommendations for a national Countdown Collaboration. Arch Dis Child 2015; 100:907-14. 
64. Tomasik T. Back to red: allowing specialists to provide primary care would be a step backward for Poland. BMJ 2014; 348:g3030.

65. Ewald DA, Huss G, Auras S, Caceres JR-C, Hadjipanayis A, Geraedts M. Development of a core set of quality indicators for paediatric primary care practices in Europe, COSI-PPC-EU. Eur J Pediatr 2018; 177:921-33.

66. Halfon N, Larson K, Lu M, Tullis E, Russ S. Lifecourse health development: past, present and future. Matern Child Health J 2014; 18:344-65.

67. Ehrich J, Burla L, Sanz AC, Crushell E, Cullu F, Fruth J, et al. As Few Pediatricians as Possible and as Many Pediatricians as Necessary? J Pediatr 2018; 202:338-339.e1. 


\begin{tabular}{|c|c|c|c|c|c|c|}
\hline $\begin{array}{l}\text { Author/year } \\
\text { publication/ } \\
\text { country }\end{array}$ & Design/quality & Participants & Comparison & Outcome variable & $\begin{array}{c}\text { Results }^{*} \\
\text { (OR or PR }[95 \% \mathrm{Cl}] \text { ) }\end{array}$ & $\begin{array}{l}\text { Results } \\
\text { favour }\end{array}$ \\
\hline $\begin{array}{l}\text { Stojanovic. }^{15} \\
2008 \\
\text { (Croatia) }\end{array}$ & $\begin{array}{l}\text { Retrospective Cohort study. } \\
\text { Medical records. } \\
\text { Medium quality }\end{array}$ & $\begin{array}{l}\text { Clinical registers of } \\
964 \text { children from } 1 \text { to } \\
6 \text { years ( } 530 \text { attended } \\
\text { by one PEDs and } 434 \\
\text { attended by } 6 \text { FDs) } \\
\text { during } 2004\end{array}$ & $\begin{array}{l}\text { Factors related to ATB } \\
\text { prescription }\end{array}$ & $\begin{array}{l}\text { Logistic regression (OR PED vs FD): } \\
\text { 1. More ATB prescription } \\
2 \text { Referral to specialist } \\
\text { 3. Referral for treatment } \\
\text { 4. Hospital referral } \\
\text { 5. Other prescriptions }\end{array}$ & $\begin{array}{l}1.3[1.0-1.6] \\
4.1[1.2-13.8] \\
4.2[1.2-14.9] \\
5.5[1.4-21.7] \\
1.8[1.4-2.3]\end{array}$ & FD \\
\hline $\begin{array}{l}\text { Clavena }^{8} 2010 \\
\text { (Italy) }\end{array}$ & $\begin{array}{l}\text { Retrospective Cohort study. } \\
\text { Medical records. } \\
\text { Medium quality }\end{array}$ & $\begin{array}{l}\text { Clinical registers of } \\
548,922 \text { children from } \\
6 \text { to } 13 \text { years }\end{array}$ & Drugs prescription. & $\begin{array}{l}\text { OR PED vs FD } \\
\text { 1.-Drugs prescription(adjusted OR) } \\
\text { 2.-ATB prescription } \\
\begin{aligned} \text { 3.-ATB type: - penicillin } \\
\text { - macrolides } \\
\text {-cephalosporins }\end{aligned}\end{array}$ & $\begin{array}{l}0.86[0.85-0.87] \\
1 \quad[0.99-1.01] . \\
1.54[1.33-1.78] \\
0.81[0.69-0.94] \\
0.76[0.65-0.89]\end{array}$ & $\begin{array}{l}\text { PED or } \\
\text { similar }\end{array}$ \\
\hline $\begin{array}{l}\text { Blommaert }^{13} \\
2013 \\
\text { (Belgium) }\end{array}$ & $\begin{array}{l}\text { Retrospective Cohorts study } \\
\text { IMA (Inter Mutualist Agency) } \\
\text { clinical registers } \\
\text { Medium quality }\end{array}$ & $\begin{array}{l}\text { Two cohorts: children } \\
1-5 \text { years and adults } \\
30-60 \text { years }\end{array}$ & $\begin{array}{l}\text { Factors related to } \\
\text { amoxicillin prescription } \\
\text { instead of amoxiclav }\end{array}$ & $\begin{array}{l}\text { Influence of type of health care provider } \\
\text { (OR PED vs FD) multivariate analysis } \\
\text { 1. Brussels (minimum and maximum } \\
\text { prescription age) } \\
\text { 2.- Flemish } \\
\text { 3.- Wallonia } \\
\text { 4.-Overall prescription children } 1 \text { year } \\
\text { Overall prescription children } 2 \text { years } \\
\text { Overall prescription children } 3 \text { years } \\
\text { Overall prescription children } 4 \text { years } \\
\text { Overall prescription children } 5 \text { years }\end{array}$ & $\begin{array}{l}\text { Min2a: OR } 2.38(95 \% \mathrm{Cl} 1.59-3.56) \\
\text { Max1a: OR2.58(95\% Cl1.71 - 3.87) } \\
\text { Min5a: OR } 1.08(95 \% \mathrm{Cl} 0.78-1.51) \\
\text { Max3a: OR1.2(95\% Cl0.91 - 1.59) } \\
\text { Better prescription by FD (no data) } \\
0.835(95 \% \mathrm{Cl}: 0.68-1.02) \\
0.852(95 \% \mathrm{Cl}: 0.68-1.05) \\
0.758(95 \% \mathrm{Cl}: 0.62-0.93) \\
0.721(95 \% \mathrm{Cl}: 0.58-0.90) \\
0.690(95 \% \mathrm{Cl}: 0.54-0.88)\end{array}$ & $\begin{array}{l}\text { PED and } \\
\text { FD }\end{array}$ \\
\hline
\end{tabular}

This article is protected by copyright. All rights reserved 


\begin{tabular}{|c|c|c|c|c|c|c|}
\hline $\begin{array}{l}\text { Pulcini }^{9} 2013 \\
\text { (France) }\end{array}$ & $\begin{array}{l}\text { Retrospective Cohorts study } \\
\text { Medical records } \\
\text { High quality }\end{array}$ & $\begin{array}{l}4921 \mathrm{FDs} \text { and } 301 \\
\text { PEDs ( } 31, .965 \\
\text { children) }\end{array}$ & $\begin{array}{l}\text { ATB prescription for } \\
\text { children under } 16 \text { years of } \\
\text { age }\end{array}$ & $\begin{array}{l}\text { Median [interquartile 50] of the prevalence } \\
\text { rate of antibiotic treatment } \\
\text {-FD vs PED ATB prescription (adjusted } \\
\text { econometric model) } \\
\text {-Type of ATB (adjusted econometric model }\end{array}$ & $\begin{array}{l}\text { FD } 43.3 \%[27-63.5] \text { PED } 28 \% \\
{[16.2 \text { - 45.6] }(P<0.001)} \\
\text { FD } 54 \% \text { more ATB than PED } \\
\text { FD } 54 \% \text { more penicillin than PED } \\
\text { FD } 141 \% \text { more macrolides than PED } \\
\text { PED more amoxiclav ( } 18 \% \text { vs } 12 \%)^{B}\end{array}$ & PEDs \\
\hline $\begin{array}{l}\text { Urkin }^{14} 2013 \\
\text { (Israel) }\end{array}$ & $\begin{array}{l}\text { Retrospective Cohort study. } \\
\text { Medical records. } \\
\text { Medium quality }\end{array}$ & $\begin{array}{l}87 \text { PEDs. 11FDs and } \\
27 G P s \text { ( } 19,865 \\
\text { children) }\end{array}$ & $\begin{array}{l}\text { Acute pharyngotonsillitis: } \\
\text { culture and early ATB } \\
\text { prescription in children 0- } \\
\text { 18years }\end{array}$ & $\begin{array}{l}\text { 1.-Perform a throat cultures in the first } \\
\text { consultation. } \\
\text { Logistic regression (OR) } \\
2 \text { Early ATB prescription(OR) }\end{array}$ & $\begin{array}{l}\text { PED }>\text { FD }(p<0.001) \\
\text { FD>GP }(p<0.001) \\
0.29[0.26-0.33] \\
\text { PED vs FD: } 0.87[0.77-1] \\
\text { PED vs GP: } 1.42[1.29-1.56]\end{array}$ & $\begin{array}{l}\text { PED more } \\
\text { throat } \\
\text { culture } \\
\text { GP fewer } \\
\text { ATB }\end{array}$ \\
\hline $\begin{array}{l}\text { Sellam }^{10} 2015 \\
\text { (France) }\end{array}$ & $\begin{array}{l}\text { Retrospective Cohort study. } \\
\text { Medical records. } \\
\text { Medium quality }\end{array}$ & $\begin{array}{l}\text { Survey of } 27 \text { PEDs } \\
\text { from an infectious } \\
\text { group and comparison } \\
\text { with PEDs and GP } \\
\text { records from the } \\
\text { French Health System }\end{array}$ & ATB prescription & $\begin{array}{l}\text { - ATB prescription (\%) }{ }^{+} \\
\text {PEDinfec (54,212 visits) } \\
\text { PED (no data on visits) } \\
\text { GP (no data on visits) } \\
\text { - ATB type for OMA treatment: } \\
\text { Amoxicillin (PEDinfec; PED; GP) } \\
\text { Amoxiclav (PEDinfec; PED; GP) } \\
\text { Cephalosporin (PEDinfec; PED; GP) } \\
\text { - Type of ATB prescribed (PEDinfec; }\end{array}$ & $\begin{array}{l}10.7 \% \\
12 \% \\
21 \%{ }^{*} \\
72.3 \% \text { vs } 44 \% \text { vs } 15 \% \\
19.3 \% \text { vs } 33 \% \text { vs } 20 \% \\
6.4 \% \text { vs } 22 \% \text { vs } 59 \%\end{array}$ & $\begin{array}{l}\text { PED } \\
\text { (7) }\end{array}$ \\
\hline $\begin{array}{l}\text { Watson }{ }^{11} 2017 \\
\text { (USA) }\end{array}$ & $\begin{array}{l}\text { Retrospective Cohort study. } \\
\text { Medical records. } \\
\text { Medium quality }\end{array}$ & $\begin{array}{l}255.291 \text { ATB } \\
\text { prescription }\end{array}$ & $\begin{array}{l}\text { Factors related to ATB } \\
\text { prescription }\end{array}$ & $\begin{array}{l}\text {-OR standardized ATB prescription rate } \\
\text { (PED vs FD) (multivariable logistic } \\
\text { regression) }\end{array}$ & $0.49[0.48-0.51]$ & PED \\
\hline $\begin{array}{l}\text { Fleming }^{12} 2018 . \\
\text { (USA) }\end{array}$ & $\begin{array}{l}\text { Retrospective Cohort study. } \\
\text { Medical records. } \\
\text { High quality }\end{array}$ & $\begin{array}{l}\text { Children below } 19 \\
\text { years }\end{array}$ & $\begin{array}{l}\text { ATB and azithromycin } \\
\text { prescription }\end{array}$ & $\begin{array}{l}\text { PR azithromycin adjusted prescription } \\
\text { (PED vs FD) } \\
0-2 \text { years } \\
\text { 3-9 years } \\
\text { 10-19years }\end{array}$ & $\begin{array}{l}0.56[0.55-0.56] \\
0.71[0.71-0.71] \\
0.85[0.85-0.85]\end{array}$ & PED \\
\hline
\end{tabular}

PED: paediatricians; FD: family doctors; GP: general practitioners; PEDinfec: infectiology Paediatricians ATB: antibiotics: Amoxicillin-Ac clavulanic: amoxiclav ( $($ ) following the indications of the

French guides (+) OR cannot be calculated due to lack of data $\left({ }^{*}\right)<1$ favours' FD/GP; $>1$ favours PEDs $\left({ }^{* *}\right): p<0,001$

This article is protected by copyright. All rights reserved 
Table 2. Studies comparing the clinical practice of PED and FD/GP in the management of otitis media

\begin{tabular}{|c|c|c|c|c|c|c|}
\hline $\begin{array}{l}\text { Author/year } \\
\text { of } \\
\text { publication/ } \\
\text { country }\end{array}$ & Design/quality & Participants & Comparison & Outcome variable & $\begin{array}{l}\text { Results* }^{*} \\
\text { (OR or PR } \\
{[95 \% \mathrm{Cl}] \text { ) }}\end{array}$ & $\begin{array}{l}\text { Results } \\
\text { favour }\end{array}$ \\
\hline $\begin{array}{l}\text { Ganga- } \\
\text { Zandzou }{ }^{16} 2009 \\
\text { (France) }\end{array}$ & $\begin{array}{l}\text { Cross-sectional } \\
\text { Study Professional } \\
\text { phone survey } \\
\text { Low quality }\end{array}$ & $\begin{array}{l}\text { Survey of } 129 \text { FDs and } 46 \text { PEDs } \\
\text { (rr: } 64.5 \% \text { FD and } 67.6 \% \text { PED) }\end{array}$ & $\begin{array}{l}\text { Adherence to CPG } \\
\text { in management of } \\
\text { AOM }\end{array}$ & $\begin{array}{l}\text { Adherence to CPG (PR PEDs vs FD) } \\
\text { >2years: observation, ATB type, dosage, length of treatment } \\
\text { <2years: ATB type, dosage, } \\
\text { length of treatment } \\
\text { Prescription ATB recommended in case of allergy: } \\
\text { Penicillin } \\
\text { Beta-lactams }\end{array}$ & $\begin{array}{l}2.36[1.45-3.82] \\
\text { n.s } \\
\text { n.s } \\
1.19[1.01-3.72] \\
2.93[1.62-5.27] \\
1.24[0.75-2.03]\end{array}$ & $\begin{array}{c}\text { PED } \\
\text { Little } \\
\text { difference }\end{array}$ \\
\hline $\begin{array}{l}\text { Grossman }^{17} \\
2012 \\
\text { (Israel) }\end{array}$ & $\begin{array}{l}\text { Retrospective } \\
\text { Cohort study. } \\
\text { Medical records. } \\
\text { Medium quality }\end{array}$ & $\begin{array}{l}292,896 \text { children diagnosed with } \\
\text { AOM and treated with ATB by } \\
\text { PED }(72.3 \%) . \text { FD/GP }(14.1 \%) \\
\text { and otolaryngologist ( } 12.7 \%) \\
\text { (2002-2009) }\end{array}$ & $\begin{array}{l}\text { Early ATB treatment } \\
\text { of AOM (in the } 3 \\
\text { days of the } \\
\text { beginning) according } \\
\text { to medical specialty }\end{array}$ & $\begin{array}{l}\text { Early ATB treatment (\% patients) }{ }^{+} \text {(variation during study period) } \\
\text { otolaryngologist } \\
\text { PED } \\
\text { FD/GP }\end{array}$ & $\begin{array}{l}-11 \%(47 \% \text { to } 36 \%)^{\star *} \\
-4 \%(46 \% \text { to } 42 \%)^{\star *} \\
+7 \%(43 \% \text { to } 50 \%)^{\star \star}\end{array}$ & PED \\
\hline $\begin{array}{l}\text { Shviro-Rosema }{ }^{18} \\
2014 \\
\text { (Israel) }\end{array}$ & $\begin{array}{l}\text { Retrospective } \\
\text { Cohort study. } \\
\text { Medical records. } \\
\text { Medium quality }\end{array}$ & $\begin{array}{l}597 \text { children diagnosed with } \\
\text { AOM and treated with ATB by } 38 \\
\text { FD, } 12 \text { PED and } 7 \text { GP } \\
\text { (participation rate } 86.7 \% \text { ) }\end{array}$ & $\begin{array}{l}\text { Adherence to CPG in } \\
\text { management of } \\
\text { AOM }\end{array}$ & $\begin{array}{l}\text { 1. Amoxicillin (OR) } \\
\text {-PED vs PEDres }{ }^{++} \\
\text {-PED vs FD } \\
\text {-PED vs GP } \\
\text { 2. Dosage appropriate to weight and CPG } \\
\text {-PED+ PEDres }{ }^{\#} \text { vs MF } \\
\text {-PED+ PEDres vs MG }\end{array}$ & $\begin{array}{l}0.57[0.26-1.24] \\
0.51[0.25-1.07] \\
0.72[0.27-1.93] \\
3.13[1.98 \text { a } 4.95] \\
6.88[3.66 \text { a } 12.93]\end{array}$ & $\begin{array}{l}\text { Same ATB } \\
\text { choice. } \\
\text { Better PED } \\
\text { and PEDres } \\
\text { than GP and } \\
\text { FD in } \\
\text { dosage }\end{array}$ \\
\hline
\end{tabular}

FD: family doctors; PED: paediatricians; GP: general practitioner; PEDres: residents of paediatrics; rr: response rate; ATB: antibiotics; AOM: acute otitis media; CPG Clinical practice guidance: OR Odds ratio

PR: Prevalence Ratio; n.s: no significant differences $\quad\left(^{*}\right)<1$ favours' FD/GP; $>1$ favours PEDs $\left({ }^{* *}\right): p<0,001\left({ }^{+}\right)$OR cannot be calculated with available data; $\left({ }^{++}\right)$listed in column FD/GP; $(\#):$ listed in column PED

This article is protected by copyright. All rights reserved 


\begin{tabular}{|c|c|c|c|c|c|c|}
\hline $\begin{array}{l}\text { Author/year of } \\
\text { publication/ } \\
\text { country }\end{array}$ & Design/quality & Participants & Comparison & Outcome variable & $\begin{array}{c}\text { Results }^{\star} \\
\text { (OR or } \\
\text { PR[95\%Cl]) }\end{array}$ & $\begin{array}{l}\text { Results } \\
\text { favour }\end{array}$ \\
\hline $\begin{array}{l}\text { Pate }^{19} 2009 \\
\text { (USA) }\end{array}$ & $\begin{array}{l}\text { Cross-sectional study Professional mail } \\
\text { survey } \\
\text { Medium quality }\end{array}$ & $\begin{array}{l}\text { Survey of } 86 \mathrm{FD} \\
\text { and } 149 \text { PED (rr: } \\
49 \% \text { ) }\end{array}$ & $\begin{array}{l}\text { Ask about cost of } \\
\text { asthma treatment }\end{array}$ & $\begin{array}{l}\text { OR (PED vs FD) } \\
\text { Ask about cost of asthma treatment }\end{array}$ & $0.71[0.57-0.86]$ & FD \\
\hline $\begin{array}{l}\text { Dombkowski }{ }^{20} 2010 \\
\text { (USA) }\end{array}$ & $\begin{array}{l}\text { Cross-sectional study Professional } \\
\text { survey } \\
\text { Medium quality }\end{array}$ & $\begin{array}{l}360 \text { surveys of } \\
150 \text { FD and } 210 \\
\text { PED (rr: } 50 \% \text { ) }\end{array}$ & $\begin{array}{l}\text { Use of spirometry in } \\
\text { children with asthma }\end{array}$ & $\begin{array}{l}\text { PR (PED vs FD) } \\
\text { Use of spirometry } \\
\text { Comfortable in interpreting spirometry results }\end{array}$ & $\begin{array}{l}0.50[0.41-0.61]^{\#} \\
0.60[0.48-0.75]\end{array}$ & FD \\
\hline $\begin{array}{l}\text { Farber }^{21} 2017 \\
\text { (USA) }\end{array}$ & $\begin{array}{l}\text { Retrospective Cohorts study } \\
\text { MEDICAID (Inter Mutualistic Agency) } \\
\text { and CHIP (Children Heath Insurance } \\
\text { Program) clinical registers } \\
\text { Medium quality }\end{array}$ & $\begin{array}{l}327,303 \text { children } \\
\text { ( } 1 \text { to } 18 \text { years) } \\
\text { diagnosed with } \\
\text { asthma between } \\
2011-2016\end{array}$ & $\begin{array}{l}\text { Prescription rates of } \\
\text { short courses of oral } \\
\text { corticosteroids. }\end{array}$ & $\begin{array}{l}\text { Short courses of oral corticosteroid prescription (one or more) } \\
\text { PED vs FD/GP/IM } \\
\text { Asthma emergency department visits/ } \\
\text { hospitalization rates as a function of the corticoid courses }\end{array}$ & $\begin{array}{l}42.1-44.2 \% \\
41-42 \% \text { vs } 46-47 \%^{* *} \\
\text { n.s }\end{array}$ & PED \\
\hline
\end{tabular}

FD: family doctors; PED: paediatricians; GP: general practitioner: IM: internal medicine physician rr: response rate; PR: prevalence ratio; n.s: non-significant differences $\left({ }^{\star}\right)<1$ favour FD/GP; >1 favour PED $\left.{ }^{* *}\right): p<0,01$

(\#)Adjusted OR in a logistic regression model with PEDs as reference: $7.6[3.7-15.4]\left(^{+}\right)$OR cannot be calculated with available data

This article is protected by copyright. All rights reserved 


\begin{tabular}{|c|c|c|c|c|c|c|}
\hline $\begin{array}{l}\text { Author/year of } \\
\text { publication/ } \\
\text { country }\end{array}$ & Design/quality & $\begin{array}{l}\text { Participan } \\
\text { ts }\end{array}$ & Comparison & Outcome variable & $\begin{array}{c}\text { Results* } \\
\text { (OR or PR[95\%Cl]) }\end{array}$ & Results favour \\
\hline $\begin{array}{l}\text { Fremont } 222008 \\
\text { (USA) }\end{array}$ & $\begin{array}{l}\text { Cross-sectional } \\
\text { study Professional } \\
\text { mail survey } \\
\text { Low quality }\end{array}$ & $\begin{array}{l}240 \text { PED/ } \\
243 \text { FD (rr: } \\
38 \%)\end{array}$ & $\begin{array}{l}\text { Diagnosis and treatment of psychiatric } \\
\text { disorders in children }\end{array}$ & $\begin{array}{l}\text { PR (PED vs FD) } \\
\text { ADHD } \\
\text { - Comfortable in diagnosing } \\
\text { - Comfortable in prescribing medication } \\
\text { ANXIETY AND DEPRESSION: } \\
\text { - Comfortable in diagnosing } \\
\text { Comfortable in prescribing medication: } \\
\text { Antidepressant medications } \\
\text { Anxiolytic medications }\end{array}$ & $\begin{array}{l}1.92[1.20-3.07] \#^{1} \\
2.20[1.39-3.45] \#^{2} \\
0.54[0.41-0.71] \#^{3} \\
0.63[0.44-0.89] \#^{4} \\
1.07[0.72-1.58] \#^{4}\end{array}$ & $\begin{array}{c}\text { Similar } \\
\text { PEDs better for } \\
\text { ADHD medication; } \\
\text { FD better for } \\
\text { anxiety and } \\
\text { depression } \\
\text { medication }\end{array}$ \\
\hline $\begin{array}{l}\text { Ronsley }^{23} 2013 \\
\text { (Canadá) }\end{array}$ & $\begin{array}{l}\text { Retrospective } \\
\text { Cohorts study } \\
\text { Clinical registers } \\
\text { (1996-2011) } \\
\text { Medium quality }\end{array}$ & $\begin{array}{l}\text { PED. FD y } \\
\text { psychiatrists }\end{array}$ & $\begin{array}{l}\text { Prescription of antipsychotics in children } \\
\text { under } 18 \text { years }\end{array}$ & $\begin{array}{l}\text { Antipsychotic prescription rate change }{ }^{+} \\
\text {Second generation antipsychotic change }{ }^{+} \\
\text {Prescription change for age and sex: } \\
-10 \text { males } 13-18 \text { years } \\
-20 \text { females } 13-18 \text { years } \\
\text { 30 males 6-12 years } \\
\text { Prescription in 2010/11 (in 1996-97) according to specialist }{ }^{+} \\
\text {-Children 0-5years (PED/GP/Psychiatrist) } \\
\text {-Children 5-11years (PED/GP/Psychiatrist) } \\
\text {-Children 13-18years (PED/GP/Psychiatrist) }\end{array}$ & $\begin{array}{l}\text { Increase } 3.8 \text { fold } \\
\text { Increase } 18.1 \text { fold } \\
\text { Increase } 4.4 \text { fold } \\
\text { Increase } 3.8 \text { fold } \\
\text { Increase } 3.7 \text { fold } \\
46.8 \% / 22.4 \% / 14.1 \% \\
14.9 \% / 27.8 \% / 29.1 \% \\
9.5 \% / 38.8 \% / 39.1 \%\end{array}$ & PED \\
\hline
\end{tabular}

FD: family doctors; PED: paediatricians; GP: general practitioner; rr: response rate; ADHD: Attention deficit/hyperactivity disorder; $\left({ }^{\star}\right)<1$ favour FD/GP; $>1$ favour PED $\left({ }^{\star \star}\right)$ :p<0,01

\#Study authors calculated Adjusted OR: \# ${ }^{1} 3.05[1.40-6.63]$; \#²4.16[1.96-8.84]; $\#^{3} 0.28[0.14-0.57]$; $\#^{4}$ (antidepressants and anxiolytics as a whole)0.44[0.22-0.87] (+) OR cannot be calculated with available data

This article is protected by copyright. All rights reserved 


\begin{tabular}{|c|c|c|c|c|c|c|}
\hline $\begin{array}{l}\text { Author/year } \\
\text { publication/ } \\
\text { country }\end{array}$ & Design/quality & Participants & Comparison & Outcome variable & $\begin{array}{c}\text { Results }^{*} \\
\text { (OR or PR } \\
[95 \% \mathrm{Cl}])\end{array}$ & $\begin{array}{l}\text { Results } \\
\text { favour }\end{array}$ \\
\hline $\begin{array}{l}\text { Dombkowski }^{30} \\
2008 \\
\text { (USA) }\end{array}$ & $\begin{array}{l}\text { Cross-sectional study. Professional } \\
\text { survey. Low quality }\end{array}$ & $\begin{array}{l}175 \text { PED and } 145 \text { FD } \\
(\mathrm{rr}: 67 \%)\end{array}$ & $\begin{array}{l}\text { Flu vaccination in children } \\
\text { with asthma }\end{array}$ & $\begin{array}{l}\text { Adjusted OR (PED vs FD) } \\
\text { Flu vaccination of children with persistent asthma } \\
\text { Vaccination of children with intermittent asthma }\end{array}$ & $\begin{array}{l}14.4(\text { no data } \mathrm{Cl})^{* * *} \\
3.62[1.72-7.60]\end{array}$ & PED \\
\hline $\begin{array}{l}\text { Gust }^{32} 2008 \\
\text { (USA) }\end{array}$ & $\begin{array}{l}\text { Cross-sectional study } \\
\text { Professional online survey } \\
\text { Medium quality }\end{array}$ & $\begin{array}{l}250 \text { PED and } 484 \text { FD } \\
(r r: 65 \%)\end{array}$ & $\begin{array}{l}\text { Attitude towards vaccine } \\
\text { recommendations }\end{array}$ & $\begin{array}{l}\text { PR (PED vs FD) } \\
\text { Recommend all immunizations } \\
\text { Adjusted OR multivariate analysis: variables } \\
\text { associated with no recommend immunization } \\
\text { (PED vs FP) }\end{array}$ & $\begin{array}{l}2.46[1.45-4.19] \\
0.34[0.17-0.71]\end{array}$ & PED \\
\hline $\begin{array}{l}\text { Kempe }^{33} 2009 \\
\text { (USA) }\end{array}$ & $\begin{array}{l}\text { Cross-sectional study } \\
\text { Professional online survey } \\
\text { High quality }\end{array}$ & 360 PED and 263 FD & $\begin{array}{l}\text { Rotavirus Vaccination at PED } \\
\text { and FD clinics }\end{array}$ & $\begin{array}{l}\text { PR (PED vs FD) } \\
\text { Routinely offering the vaccine } \\
\text { Do not offer RV } \\
\text { RV offered but not routinely } \\
\text { Knowledge of 1st dose dosage } \\
\text { Knowledge of 3rd dose dosage } \\
\text { RV security doubts } \\
\text { Doubts about over-vaccination } \\
\text { Economic barriers }\end{array}$ & $\begin{array}{l}2.65[2.10-3.57] \\
0.39[0.30-0.51] \\
0.38[0.22-0.64] \\
2.01[1.72-2.36] \\
1.67[1.45-1.93] \\
0.51[0.37-0.69] \\
0.41[0.27-0.60] \\
0.92[0.77-1.10]\end{array}$ & PED \\
\hline $\begin{array}{l}\text { Kempe }^{35} 2010 \\
\text { (USA) }\end{array}$ & $\begin{array}{l}\text { Cross-sectional study } \\
\text { Professional online survey } \\
\text { High quality }\end{array}$ & $\begin{array}{l}219 \text { PED and } 135 \\
\text { FD (rr: } 68 \% \text { y } 51 \% \text { ) }\end{array}$ & $\begin{array}{l}\text { Hib vaccination during a } \\
\text { period of vaccine shortage }\end{array}$ & $\begin{array}{l}\text { PR (PED vS FD) } \\
\text { Know ACIP recommendations during supply } \\
\text { failure Hib } \\
\text { Do not vaccinate low-risk children } \\
\text { Vaccinate high-risk children }\end{array}$ & $\begin{array}{l}4.98[1.99-12.43] \\
1.27[1.02-1.57] \\
0.79[0.55-1.13]\end{array}$ & PED \\
\hline $\begin{array}{l}\text { Daley }^{24} 2010 \\
\text { (USA) }\end{array}$ & $\begin{array}{l}\text { Cross-sectional study } \\
\text { Professional survey } \\
\text { High quality }\end{array}$ & $\begin{array}{l}349 \text { PED and } 331 \text { FD } \\
\text { (rr: } 81 \% \text { and } 79 \%)\end{array}$ & $\begin{array}{l}\text { HPV vaccination by PED and } \\
\text { FD }\end{array}$ & $\begin{array}{l}\text { PR (PED vs FD) } \\
\text { HPV recommendation } \\
\text {-Of recommended:female11-12y }\end{array}$ & $\begin{array}{l}3.63[1.82-7.12] \\
1.14[0.98-1.32]\end{array}$ & PED \\
\hline
\end{tabular}

This article is protected by copyright. All rights reserved 


\begin{tabular}{|c|c|c|c|c|c|c|}
\hline & & & & -Of recommended: female 13-15y & $1.22[0.93-1.57]$ & \\
\hline $\begin{array}{l}\text { Kempe }^{40} 2011 \\
\text { (USA) }\end{array}$ & $\begin{array}{l}\text { Cross-sectional study Professional } \\
\text { survey. High quality }\end{array}$ & $\begin{array}{l}357 \text { PED and } 262 \text { FD } \\
\text { (rr: } 88 \% \text { and } 78 \%)\end{array}$ & $\begin{array}{l}\text { Prevalence of doubts regarding } \\
\text { vaccination in families }\end{array}$ & $\begin{array}{l}\text { PR (PED vs FD) } \\
\text { Require parents to sign if they refuse vaccinations } \\
\text { Reject anti-vaccine families }\end{array}$ & $\begin{array}{l}1.45[1.27-1.66] \\
1.79[1.61-1.98]\end{array}$ & $\begin{array}{l}\text { NOT } \\
\text { CLEAR }\end{array}$ \\
\hline $\begin{array}{l}\text { Vadaparampil } \\
2011 \\
\text { (USA) }\end{array}$ & $\begin{array}{l}\text { Cross-sectional study } \\
\text { Professional survey } \\
\text { Medium quality }\end{array}$ & $\begin{array}{l}287 \text { PED and } 500 \text { FD } \\
(r r: 68 \%)\end{array}$ & $\begin{array}{l}\text { HPV recommendation at } 11- \\
12 y \text { and } 13-17 y\end{array}$ & $\begin{array}{l}\text { PR (PED vs FD) } \\
\text { High knowledge about HPV } \\
\text { Perceiving barriers to vaccination } \\
\text { OR logistic regression model (PED vs FD) } \\
\text { Always recommends HPV at age 11-12 } \\
\text { Always recommends HPV at age } 13-17\end{array}$ & $\begin{array}{l}0.73[0.61-0.88] \\
0.64[0.52-0.79] \\
2.6[1.9-3.7] \\
4.7[3.4-6.6]\end{array}$ & PED \\
\hline $\begin{array}{l}\text { Toback }^{31} 2012 \\
\text { (USA) }\end{array}$ & $\begin{array}{l}\text { Cross-sectional study } \\
\text { Professional survey } \\
\text { Medium quality }\end{array}$ & $\begin{array}{l}105 \text { PED offices and } \\
13 \text { FD offices }\end{array}$ & $\begin{array}{l}\text { Attitude in regard to flu } \\
\text { vaccine }\end{array}$ & $\begin{array}{l}\text { PR (PED offices vs FD offices) } \\
\text { Recommend vaccine to all child } 6 \text { month-5y } \\
\text { Recommend vaccine to no high risk child 5-18y } \\
\text { Recommend vaccine to high-risk child 5-18y }\end{array}$ & $\begin{array}{l}1[1-1] \\
1.19[0.93-1.5] \\
1.35[0.76-2.39]\end{array}$ & SAME \\
\hline $\begin{array}{l}\text { Pruvost }^{3 /} 2012 \\
\text { France }\end{array}$ & $\begin{array}{l}\text { Cross-sectional study } \\
\text { Professional survey } \\
\text { Medium quality }\end{array}$ & $\begin{array}{l}43 \text { PED and } 109 \text { FD } \\
(r r: 61 \%)\end{array}$ & $\begin{array}{l}\text { Adherence to the vaccine } \\
\text { schedule for MMR, pertussis, } \\
\text { and pneumococcus }\end{array}$ & $\begin{array}{l}\text { PR (PED vs FD) } \\
\text { Adherence to pneumococcal vaccination schedule } \\
\text { Adherence to pertussis vaccination schedule } \\
\text { Adherence to MMR vaccination schedule }\end{array}$ & $\begin{array}{l}12.10[1.73-84.73] \\
1.49[0.89-2.46] \\
2.14[1.32-3.47]\end{array}$ & PED \\
\hline $\begin{array}{l}\text { O'Leary }^{34} 2013 \\
\text { (USA) }\end{array}$ & $\begin{array}{l}\text { Cross-sectional study } \\
\text { Professional survey } \\
\text { Medium quality }\end{array}$ & $\begin{array}{l}285 \text { PED and } 192 \text { FD } \\
\text { (rr:70\% and } 61 \%)\end{array}$ & Rotavirus vaccine practices & $\begin{array}{l}\text { PR (PED vs FD) } \\
\text { Recommend the vaccine } \\
\text { Inform but not recommend } \\
\text { Administer the vaccine } \\
\text { Doubts about security }\end{array}$ & $\begin{array}{l}3.93[2.28-6.76] \\
0.24[0.13-0.43] \\
3.96[2.44-6.40] \\
0.28[0.17-0.45]\end{array}$ & PED \\
\hline $\begin{array}{l}\text { Tolaymat }^{36} \\
2013 \\
\text { (USA) } \\
\text { (oral } \\
\text { communication } \\
\text { ) }\end{array}$ & $\begin{array}{l}\text { Cross-sectional study } \\
\text { Professional survey } \\
\text { Low quality }\end{array}$ & $\begin{array}{l}26 \text { PED, } 34 \text { FD and } \\
18 \text { residents }\end{array}$ & $\begin{array}{l}\text { Knowledge of vaccination in } \\
\text { children with inflammatory } \\
\text { bowel disease and } \\
\text { immunosuppressive therapy }\end{array}$ & $\begin{array}{l}\text { PR (PED vs FD) } \\
\text { Identify attenuated vaccines as unsafe }\end{array}$ & $2.25[1.16-4.36]$ & PED \\
\hline
\end{tabular}

This article is protected by copyright. All rights reserved 


\begin{tabular}{|c|c|c|c|c|c|c|}
\hline $\begin{array}{l}\text { O'leary }^{41} 2015 \\
\text { (USA) }\end{array}$ & $\begin{array}{l}\text { Cross-sectional study } \\
\text { Professional survey } \\
\text { High quality }\end{array}$ & $\begin{array}{l}282 \text { PED and } 252 \\
\text { FD. (rr: } 66 \% \text { y } 61 \% \text { ) }\end{array}$ & $\begin{array}{l}\text { Prevalence of vaccine } \\
\text { rejection and attitude towards } \\
\text { it }\end{array}$ & $\begin{array}{l}\text { Parents' request not to meet immunization } \\
\text { schedule (all): 1-4 / month rejection } \\
\text { At least 1request/month vaccine delay } \\
\text { PR (PED vs FD) } \\
\text { Require parents to sign if they refuse vaccinations } \\
\text { Reject anti-vaccine families } \\
\text { Asking about attitudes to vaccines in prenatal visit }\end{array}$ & $\begin{array}{l}63 \% \text { (PED 68\%; MF } \\
57 \% \text { ) } \\
83 \% \text { (PED 88\%; MF } \\
76 \%) \\
\text { PR } 1.96[1.65-2.33] \\
\text { PR } 1.78[1.56-2.04] \\
\text { PR } 1.58[1.34-1.85]\end{array}$ & MIXED \\
\hline $\begin{array}{l}\text { Kulczcki }^{26} \\
2016 \\
\text { (USA) }\end{array}$ & $\begin{array}{l}\text { Cross-sectional study } \\
\text { Professional survey } \\
\text { Medium quality }\end{array}$ & $\begin{array}{l}151 \text { PED and } 148 \text { FD } \\
(r r: 43 \%)\end{array}$ & $\begin{array}{l}\text { Prescription of HPV vaccine in } \\
\text { primary care }\end{array}$ & $\begin{array}{l}\text { PR (PED vs FD) } \\
\text { HPV Prescription } \\
\text { Multivariate logistic regression. OR(PED vs FD) }\end{array}$ & $\begin{array}{l}1.06[0.83-1.34] \\
0.57[0.30-1.09]\end{array}$ & SAME \\
\hline $\begin{array}{l}\text { Allison } 272016 \\
\text { (USA) }\end{array}$ & $\begin{array}{l}\text { Cross-sectional study } \\
\text { Professional survey } \\
\text { High quality }\end{array}$ & $\begin{array}{l}364 \text { PED and } 218 \text { FD } \\
(r r: 82 \% \text { and } 56 \%)\end{array}$ & $\begin{array}{l}\text { HPV vaccine } \\
\text { recommendations at 11-12 y } \\
\text { and delay frequency }\end{array}$ & $\begin{array}{l}\text { PR (PED vs FD) } \\
\text { Vaccine recommendation } \\
\text { Talk about the vaccine. 11th visit. }\end{array}$ & $\begin{array}{l}1.01[0.89-1.15] \\
1.27[1.05-1.54]\end{array}$ & $\begin{array}{l}\text { SAME/PE } \\
\text { D }\end{array}$ \\
\hline $\begin{array}{l}\text { Levy }^{39} 2016 \\
\text { (France) }\end{array}$ & $\begin{array}{l}\text { Cross-sectional study } \\
\text { Professional survey } \\
\text { Low quality }\end{array}$ & $\begin{array}{l}939 \text { PED and } 502 \text { FD } \\
\text { (rr: } 12 \%)\end{array}$ & $\begin{array}{l}\text { Doctors perceptions after } \\
\text { meningitis B vaccine } \\
\text { commercialization }\end{array}$ & $\begin{array}{l}\text { PR (PED vs FD) } \\
\text { Knowing the existence of the vaccine } \\
\text { Know the vaccine schedule } \\
\text { Have started vaccination }\end{array}$ & $\begin{array}{l}2.34[2.01-2.71] \\
1.67[1.56-1.78] \\
1.41[1.30-1.53]\end{array}$ & PED \\
\hline $\begin{array}{l}\text { Vie le sagne }^{38} \\
2016 \\
\text { (France) }\end{array}$ & $\begin{array}{l}\text { Cross-sectional study } \\
\text { Professional phone survey } \\
\text { Medium quality }\end{array}$ & $\begin{array}{l}463 \text { PED (232 T1, } \\
231 \mathrm{~T} 2) \text { and } 418 \mathrm{FD} \\
(192 \mathrm{~T} 1,296 \mathrm{~T} 2)\end{array}$ & $\begin{array}{l}\text { Acceptability of hepatitis B } \\
\text { vaccine after reimbursement }\end{array}$ & $\begin{array}{l}\text { PR (PED vS GP) } \\
\text { Vaccination at the beginning } \\
\text { Vaccination at } 3 \text { years (final) } \\
\text { Hepatitis B vaccine recommendation at the } \\
\text { beginning } \\
\text { Hepatitis B vaccine recommendation at } 3 \text { years }\end{array}$ & $\begin{array}{l}1.08[0.95-1.22] \\
2.64[1.83-3.81] \\
2.96[2.11-4.14] \\
2.73[1.70-4.36]\end{array}$ & PED \\
\hline $\begin{array}{l}\text { Wilburg }^{29} 2016 \\
\text { (Poster) } \\
\text { (USA) }\end{array}$ & $\begin{array}{l}\text { Retrospective Cohorts study } \\
\text { Medical records. } \\
\text { Medium quality }\end{array}$ & $\begin{array}{l}\text { Medical records } \\
(2006-2013)\end{array}$ & $\begin{array}{l}\text { HPV vaccination and } \\
\text { relationship with type of } \\
\text { professional }\end{array}$ & $\begin{array}{l}\text { OR (PED vs FD) } \\
\text { Initiate vaccination } \\
\text { Complete vaccination }\end{array}$ & $\begin{array}{l}1.41 \text { [no data] } \\
1.53 \text { [no data] }\end{array}$ & PED \\
\hline $\begin{array}{l}\text { Kempe }^{42} 2017 \\
\text { (USA) }\end{array}$ & $\begin{array}{l}\text { Cross-sectional study Professional } \\
\text { survey. High quality }\end{array}$ & $\begin{array}{l}325 \text { PED. } 310 \mathrm{FD} \\
(\mathrm{rr}: 75 \% \text { and } 68 \%)\end{array}$ & $\begin{array}{l}\text { Knowledge of official } \\
\text { vaccination registration }\end{array}$ & $\begin{array}{l}\text { PR (PED vs FD) } \\
\text { They do not know of the existence of a register }\end{array}$ & $0.51[0.33-0.77]$ & PED \\
\hline
\end{tabular}

This article is protected by copyright. All rights reserved 


\begin{tabular}{|c|c|c|c|c|c|c|}
\hline & & & systems & Use the register & $1.30[1.06-1.60]$ & \\
\hline $\begin{array}{l}\text { Finney } \\
\text { Rutten }^{28} 2017 \\
\text { (USA) }\end{array}$ & $\begin{array}{l}\text { Cross-sectional study Professional } \\
\text { survey } \\
\text { Media quality }\end{array}$ & 43 PED and 177 FD & $\begin{array}{l}\text { HPV vaccine recommendation } \\
\text { and its relationship to } \\
\text { vaccination rates }\end{array}$ & $\begin{array}{l}\text { PR (PED vs FD) } \\
\text { HPV strongly recommended to girls } \\
\text { HPV strongly recommended to boys } \\
\text { HPV always/usually recommended to girls } \\
\text { HPV always/usually recommended to boys }\end{array}$ & $\begin{array}{l}5.84[1.87-18.21] \\
5.46[2.23-13.34] \\
11.10[1.57-78.54] \\
7.92[2.53-24.80]\end{array}$ & PED \\
\hline
\end{tabular}

FD: family doctors; PED: paediatricians; GP: general practitioners; rr: response rate; PR: prevalence ratio, T1: first period; T2: second period ,RV: rotavirus vaccines; Hib: Haemophilus influenzae type b HPV: human papillomavirus vaccine; MMR: measles, mumps, rubella y: years; ACIP: Advisory Committee on Immunization Practices $\left({ }^{*}\right)<1$ favours FD/GP; $>1$ favours PEDs (**):p<0,001;

$\left(^{* * *}\right): p<0.01\left(^{+}\right)$OR cannot be calculated with available data

This article is protected by copyright. All rights reserved 


\begin{tabular}{|c|c|c|c|c|c|c|}
\hline $\begin{array}{l}\text { Author/year } \\
\text { publication/ } \\
\text { country }\end{array}$ & Design/quality & Participants & Comparison & Outcome variable & $\begin{array}{c}\text { Results }^{*} \\
\text { (OR or } \\
\text { PR[95\%Cl]) }\end{array}$ & $\begin{array}{l}\text { Results } \\
\text { favour }\end{array}$ \\
\hline $\begin{array}{l}\mathrm{HE}^{43} \cdot 2010 \\
\text { (Canada) }\end{array}$ & $\begin{array}{l}\text { Cross-sectional study } \\
\text { Professional mail survey } \\
\text { Low quality }\end{array}$ & $\begin{array}{l}396 \text { PED and } 464 \text { FD (rr: } 46 \% \\
\text { and } 48 \% \text { ) }\end{array}$ & $\begin{array}{l}\text { Diagnosis and treatment of } \\
\text { paediatric obesity/overweight }\end{array}$ & $\begin{array}{l}\text { PR (PED vs FD) } \\
\text { Consider should be treated even if there is no } \\
\text { associated morbidity. } \\
\text { Use the recommended method/tool for classifying } \\
\text { overweight/obesity } \\
\text { Use recommended criteria for diagnosis obesity }\end{array}$ & $\begin{array}{l}1.39[1.05-1.83] \\
1.93[1.66-2.24] \\
1.52[1.38-1.67]\end{array}$ & PED \\
\hline $\begin{array}{l}\text { Hunag }^{44} 2011 \\
\text { (USA) }\end{array}$ & $\begin{array}{l}\text { Cross-sectional study } \\
\text { Professional survey } \\
\text { Low quality }\end{array}$ & $\begin{array}{l}440 \text { PED and } 371 \text { FD (rr: } \\
73.7 \% \text { and } 66.9 \%)\end{array}$ & $\begin{array}{l}\text { Diagnosis and treatment of } \\
\text { paediatric obesity/overweight }\end{array}$ & $\begin{array}{l}\text { OR (PED vs FD) (logistic regression) } \\
\text { Provide general advice } \\
\text { Advice on specific diet topics } \\
\text { Recommend physical activity Referral to specialist } \\
\text { Systematic follow-up } \\
\text { PR (PED vs FD) } \\
\text { Calculate BMI on a regular basis } \\
\text { Use of BMI charts }\end{array}$ & $\begin{array}{c}1.75[1.35-2.27] \\
2.32[1.78-3.03] \\
1.61[1.25-2.12] \\
1.56[1.03-2.32] \\
1.49[1.10-2.00] \\
1.61[1.37-1.89] \\
1.77[1.53-2.43]\end{array}$ & PED \\
\hline $\begin{array}{l}\text { Harkins }^{45} 2012 \\
\text { (USA) }\end{array}$ & $\begin{array}{l}\text { Cross-sectional study } \\
\text { Professional mail survey } \\
\text { Low quality }\end{array}$ & 119 PED and 61FD (rr: 54\%) & $\begin{array}{c}\text { Knowledge and application of CPG } \\
\text { on obesity }\end{array}$ & $\begin{array}{l}\text { PR (PED vs FD) } \\
\text { Knowledge of obesity CPG } \\
\text { Adherence to the CPG by those who knew them } \\
\text { Adequate diagnostics with BMI charts } \\
\text { Recommendation for physical activity of } 1 \text { or more } \\
\text { hours/day } \\
\text { Recommendation to limit screen time to less than } 2 \\
\text { hours/day } \\
\text { Adherence to food recommendations }\end{array}$ & $\begin{array}{l}1.51[1.10-2.08] \\
\text { n.s. } \\
1.71[1.27-2.28] \\
0.81[0.65-1.006] \\
1.49[1.20-1.85] \\
1.28[1.04-1.56]\end{array}$ & PED \\
\hline
\end{tabular}

This article is protected by copyright. All rights reserved 


\begin{tabular}{|c|c|c|c|c|c|c|}
\hline $\begin{array}{l}2013 \\
\text { (USA) }\end{array}$ & $\begin{array}{l}\text { Professional online survey } \\
\text { Medium quality }\end{array}$ & $\begin{array}{l}\text { athletic directors (rr: } 72 \% .56 \% \\
\text { y } 78 \% \text { ) }\end{array}$ & $\begin{array}{l}\text { national guidelines } \\
\text { for sudden cardiac death screening. }\end{array}$ & Follow-up of the guidelines(all items) & $1.15[0.89-1.48]$ & \\
\hline $\begin{array}{l}\text { Dixon }^{4 /} 2014 \\
\text { (USA) }\end{array}$ & $\begin{array}{l}\text { Cross-sectional study } \\
\text { Professional online survey } \\
\text { Medium quality }\end{array}$ & $\begin{array}{l}230 \text { PED. } 265 \text { FD/GP and } 39 \\
\text { advanced practitioners (AP) } \\
(r r=37 \%, 37 \% / 11 \% \text { and } \\
5.5 \%)\end{array}$ & $\begin{array}{l}\text { knowledge, screening, and } \\
\text { management attitudes regarding } \\
\text { paediatric lipid } \\
\text { guidelines. }\end{array}$ & $\begin{array}{l}\text { PR (PED vs FD): } \\
\text { Familiarized with lipid values } \\
\text { Comfortable with handling children with lipid disorders } \\
\text { Promote healthy lifestyles } \\
\text { Recommend low-fat diet } \\
\text { Should use lipid-lowering medications }\end{array}$ & $\begin{array}{l}2.72[2.25-3.27] \\
1.38[1.13-1.67] \\
1.80[1.41-2.28] \\
1.46[1.21-1.74] \\
2.43[2.03-2.89]\end{array}$ & PED \\
\hline
\end{tabular}

FD: family doctor; PED: paediatricians; GP: general practitioner; rr: response rate; CPG Clinical practice guidelines n.s: not significant ${ }^{\star}$ ) <1 favour FD/GP; >1 favours PEDs ; ; n.s: no significant differences

This article is protected by copyright. All rights reserved 


\begin{tabular}{|c|c|c|c|c|c|c|}
\hline $\begin{array}{l}\text { Author/year } \\
\text { publication/ } \\
\text { country }\end{array}$ & Design/quality & Participants & Comparison & Outcome variable & $\begin{array}{c}\text { Results }^{*} \\
\text { (OR or PR } \\
{[95 \% \mathrm{Cl}] \text { ) }}\end{array}$ & $\begin{array}{l}\text { Results } \\
\text { favour }\end{array}$ \\
\hline $\begin{array}{c}\text { McClave }{ }^{48} 201 \\
0 \\
\text { (USA) }\end{array}$ & $\begin{array}{l}\text { Cross-sectional study } \\
\text { Professional survey } \\
\text { Low quality }\end{array}$ & $\begin{array}{l}84 \text { primary care } \\
\text { PED, } 31 \\
\text { PEDsubspec and } 48 \\
\text { GP (rr: } 19,61 \%)\end{array}$ & $\begin{array}{l}\text { Awareness of the choking } \\
\text { game and its warning signs }\end{array}$ & $\begin{array}{l}\text { PR awareness of its warning signs, } \\
\text { PED vs GP } \\
\text { PED vs PEDsubspec } \\
\text { PEDsubspec vs GP }\end{array}$ & $\begin{array}{l}1.48[1.03-2.12] \\
1.41[1.02-1.95] \\
0.92[0.53-1.59]\end{array}$ & PED \\
\hline $\begin{array}{l}\text { Herndon }^{49} \\
2010 \text { (USA) }\end{array}$ & $\begin{array}{l}\text { Cross-sectional study } \\
\text { Professional survey } \\
\text { Low quality }\end{array}$ & $\begin{array}{l}264 \text { PED and } 157 \\
\text { FD (rr: } 31 \%)\end{array}$ & $\begin{array}{l}\text { Oral health knowledge confidence and } \\
\text { practice patterns. }\end{array}$ & $\begin{array}{l}\text { Multivariate analysis. Just differences: } \\
\text { 1-Fluoride-related knowledge } \\
\text { 2-Greater confidence in parents' advice }\end{array}$ & $\begin{array}{l}\text { Best PED } \\
\text { Best PED }\end{array}$ & PED \\
\hline $\begin{array}{l}\text { Burney }^{50} 2011 \\
\text { (USA) }\end{array}$ & $\begin{array}{l}\text { Cross-sectional study } \\
\text { Professional on line } \\
\text { survey (pre- and post- } \\
\text { training survey). } \\
\text { Low quality }\end{array}$ & $\begin{array}{l}57 \text { PED (rr: } 58 \%) \\
\text { and } 24 \text { FD (rr: 62\%) }\end{array}$ & $\begin{array}{l}\text { Practice in relation to screening for } \\
\text { anaemia or sickle cell trait }\end{array}$ & $\begin{array}{l}\text { PR (PED vs FD) } \\
\text { Routinely review screening tests for sickle cell disease in new } \\
\text { born infants: }\end{array}$ & $0.73[0.54-0.98]$ & FD \\
\hline $\begin{array}{l}\text { Hayeems }^{51} \\
2013 \\
\text { (Canada) }\end{array}$ & $\begin{array}{l}\text { Cross-sectional study } \\
\text { Professional survey } \\
\text { Low quality }\end{array}$ & $\begin{array}{l}273 \text { PED, } 296 \text { FD y } \\
250 \text { midwives (rr: } \\
51 \%, 63 \% \text { and } 77 \% \text { ) }\end{array}$ & $\begin{array}{l}\text { Information to families who receive } \\
\text { positive screening results } \\
\text { for their new-borns. }\end{array}$ & $\begin{array}{l}\text { PR (PED vs FD) } \\
\text { 1- Agreed that it was them } \\
\text { responsibility to provide care to families } \\
\text { 2- In favour of having specific and detailed informative talk } \\
\text { versus general information or brochure } \\
\text { 3.- Hold a specific and detailed informative talk in practice } \\
\text { 4.- Recognize lack of training on the subject } \\
\text { 5- Be updated on the Ontario Screening Program } \\
\text { 6- Confidence in knowing how to explain screening results to } \\
\text { parents }\end{array}$ & $\begin{array}{l}1.53[1.15-2.08] \\
2.63[2.10-3.27] \\
2.23[1.85-2.68] \\
0.42[0.33-0.52] \\
2.38[1.95-2.90] \\
2.77[2.25-3.40]\end{array}$ & PED \\
\hline $\begin{array}{l}\text { Vyas }^{52} 2013 \\
\text { (USA) }\end{array}$ & $\begin{array}{l}\text { Cross-sectional study } \\
\text { Professional survey } \\
\text { Low quality }\end{array}$ & $\begin{array}{l}88 \text { PED and } 49 \text { FD } \\
\text { (rr: } 64,2 \% \text { and } \\
35,8 \%)\end{array}$ & $\begin{array}{l}\text { Knowledge and use of WHO growth } \\
\text { charts }\end{array}$ & $\begin{array}{l}\text { PR (PED vs FD) } \\
\text { Knowledge of existence of WHO charts and recommendations } \\
\text { Use of WHO charts }\end{array}$ & $\begin{array}{l}1.42[1.03-1.96] \\
0.96[0.73-1.27]\end{array}$ & PED \\
\hline Knudson $^{53}$ & Cross-sectional study & 148 PED and 178 & Adherence to AHA Guidelines for the & PR (PED vs FD) & & PED \\
\hline
\end{tabular}

This article is protected by copyright. All rights reserved 


\begin{tabular}{|c|c|c|c|c|c|c|}
\hline $\begin{array}{l}2016 \\
\text { (USA) }\end{array}$ & $\begin{array}{l}\text { Professional online } \\
\text { survey } \\
\text { Low quality }\end{array}$ & $\begin{array}{l}\text { GP (rr: } 29 \% \text { and } \\
13 \%)\end{array}$ & $\begin{array}{l}\text { management of neurodevelopmental } \\
\text { disorders in Children with } \mathrm{CHD}\end{array}$ & $\begin{array}{l}\text { know the AHA recommendations } \\
\text { Rarely referred for developmental eval } \\
\text { Other items studied }\end{array}$ & $\begin{array}{l}1,54[1.28-1.85] \\
0.68[0.47-0.96] \\
\text { n.s }\end{array}$ & \\
\hline $\begin{array}{l}\text { Ayou }^{54} 2017 \\
\text { (France) }\end{array}$ & $\begin{array}{l}\text { Cross-sectional study } \\
\text { Professional mail survey } \\
\text { Low quality }\end{array}$ & $\begin{array}{l}134 \text { PED (rr: 48\%) } \\
\text { and } 298 \text { FD } \\
\text { (previous survey) }\end{array}$ & $\begin{array}{l}\text { Knowledge and practice about child } \\
\text { abuse and neglect }\end{array}$ & $\begin{array}{l}\text { PED vs GP } \\
\text { General Average Scoremax160) } \\
\text { Score on clinical practice }(\max 120) \\
\text { Score on knowledge }(\max 60)\end{array}$ & $\begin{array}{l}87.98 \text { vs } 77.88^{* \star} \\
52.84 \text { vs } 47.65^{\star \star \star} \\
29.5 \text { vs } 24.2^{\star \star}\end{array}$ & PED \\
\hline $\begin{array}{c}\text { Moore }^{55} 2017 \\
\text { (USA) }\end{array}$ & $\begin{array}{l}\text { Cross-sectional study } \\
\text { Professional survey } \\
\text { Low quality }\end{array}$ & $\begin{array}{l}34 \text { PED and } 16 \text { FD } \\
\text { (rr: } 38.5 \%)\end{array}$ & $\begin{array}{l}\text { Knowledge and practice of psychomotor } \\
\text { development screening }\end{array}$ & $\begin{array}{l}\text { PR (PED vs FD) } \\
\text { Perform PDS always } \\
\text { Interpreting the screening tests } \\
\text { Review results with parents } \\
\text { Informing parents and writing of PDS } \\
\text { Referral to Early Care }\end{array}$ & $\begin{array}{l}1.82[1.01-3.25] \\
2.60[0.8-8.51] \\
3.51[1.02-12.05] \\
1.99[1.10-3.60] \\
5.35[0.87-33.22]\end{array}$ & PED \\
\hline
\end{tabular}

AHA: American Heart Association; CHD congenital heart disease; FD: family doctors; PED: paediatricians; GP: general practitioner; rr: response rate; PR: prevalence ratio, PEDsubspec: paediatric subspecialists PDS: psychomotor development screening; WHO: World Health Organization; $\left({ }^{*}\right)<1$ favours' FD/GP; $>1$ favours PEDs, $\left({ }^{* *}\right)$ :p<0,001; $\left({ }^{* * \star}\right)$;p<0.01; n.s: $\left({ }^{\star * \star *}\right)$ p $<0.05$; no significant differences; $\left(^{+}\right)$OR cannot be calculated with available data

This article is protected by copyright. All rights reserved 


\begin{tabular}{|c|c|c|c|c|c|c|}
\hline $\begin{array}{c}\text { Author/year } \\
\text { publication/ } \\
\text { country }\end{array}$ & Design/quality & Participants & Comparison & Outcome variable & $\begin{array}{l}\text { Results* }^{\star} \\
\text { (OR or PR } \\
{[95 \% \mathrm{Cl}] \text { ) }}\end{array}$ & $\begin{array}{l}\text { Results } \\
\text { favour }\end{array}$ \\
\hline $\begin{array}{l}\text { Park }^{56} 2013 \\
\text { (France) }\end{array}$ & $\begin{array}{l}\text { Cross-sectional study } \\
\text { Professional survey } \\
\text { Low quality }\end{array}$ & $\begin{array}{l}46 \text { PED and } 36 \\
\text { FD (rr: } 74 \% \text { vs } \\
18 \%)\end{array}$ & $\begin{array}{l}\text { Use rapid strep test and prescription } \\
\text { of ATB }\end{array}$ & $\begin{array}{l}\text { PR (PED vs FD) } \\
\text { Use rapid strep test in }>3 \text { years } \\
\text { Prescribe ATB with strep rapid test - }\end{array}$ & $\begin{array}{l}1.33[0.87-2.02] \\
0.54[0.39-0.74]\end{array}$ & PED \\
\hline $\begin{array}{l}\text { Mateo }^{57} 2013 \\
\text { (Canada) }\end{array}$ & $\begin{array}{l}\text { Cross-sectional study } \\
\text { Professional survey } \\
\text { Medium quality }\end{array}$ & $\begin{array}{l}152 \text { PED and } \\
81 F D / G P(r r: \\
17 \%)\end{array}$ & $\begin{array}{l}\text { Compliance with national guidelines } \\
\text { for screening, post discharge follow- } \\
\text { up, and management of new-borns } \\
\text { with hyperbilirubinemia. }\end{array}$ & $\begin{array}{l}\text { PR (PED vs FD) } \\
\text { Follow recommendations } \\
\text { Control before } 72 \text { hours of the hospital discharge of the new born baby } \\
\text { Correct response to a jaundice case scenario }\end{array}$ & $\begin{array}{l}1.76[1.36-2.26] \\
2.23[1.49-2.31] \\
5.37[0.85-33.66]\end{array}$ & PED \\
\hline $\begin{array}{l}\text { Pham }^{58} 2014 \\
\text { (France) }\end{array}$ & $\begin{array}{l}\text { Cross-sectional study } \\
\text { Professional survey } \\
\text { Medium quality }\end{array}$ & $\begin{array}{l}256 \mathrm{GP}, 221 \\
\text { gastroenterologist } \\
\text { and } 227 \text { PED }\end{array}$ & $\begin{array}{l}\text { Adherence to diagnostic guidelines } \\
\text { of } C D\end{array}$ & $\begin{array}{l}\text { PR (PED vs GP) } \\
\text { suspected CD from GI symptoms }<2 y \\
\text { suspected CD from GI symptoms } 2-18 y \\
\text { suspected EC by weight/size }<2 y \\
\text { suspected } E C \text { by weight/size } 2-18 \text { y } \\
\text { suspected CD from general symptoms }<2 y \\
\text { suspected CD from general symptoms } 2-18 y \\
\text { use of antitransglutaminase antibodies for } d x \\
\text { use of anti-endomysium antibodies for } d x\end{array}$ & $\begin{array}{l}1.40[1.08-1.80] \\
1.42[1.12-1.81] \\
2.53[1.77-3.59] \\
1.95[1.56-2.43] \\
1.53[1.27-1.83] \\
1.50[1.25-1.80] \\
4.54[2.46-8.34] \\
0.61[0.50-0.73]\end{array}$ & PED \\
\hline $\begin{array}{l}\text { Lee }^{59} \cdot 2014 \\
\text { (USA) }\end{array}$ & $\begin{array}{l}\text { Cross-sectional study } \\
\text { Professional mail } \\
\text { survey } \\
\text { Medium quality }\end{array}$ & $\begin{array}{l}352 \text { PED and } 25 \\
2 F D(r r: 43 \%)\end{array}$ & $\begin{array}{l}\text { Screening for type } 2 \mathrm{DM} \text { in } \\
\text { adolescents and adherence to } \mathrm{ADA} \\
\text { recommendations }\end{array}$ & $\begin{array}{l}\text { PR (PED vS FD) } \\
\text { HbAC1 screening of patients at risk of DM T2 } \\
\text { At least one fasting test (plasma glucose or glucose tolerance) } \\
\text { know the ADA guides } \\
\text { Include HbA1C in initial screening }\end{array}$ & $\begin{array}{l}1.53[1.06-2.21] \\
1.26[1.09-1.47] \\
0.64[0.54-0.75] \\
1.28[1.11-1.48]\end{array}$ & PED \\
\hline $\begin{array}{l}\text { Gupt }^{60} 2015 \\
\text { (Canada) }\end{array}$ & $\begin{array}{l}\text { Retrospective } \\
\text { population-based } \\
\text { cohort study } \\
\text { Medium quality }\end{array}$ & $\begin{array}{l}1541 \text { children } \\
\text { with acute } \\
\text { lymphoblastic } \\
\text { leukaemia }\end{array}$ & Factors related to delayed diagnosis & $\begin{array}{l}\text { Logistic regression. Adjusted OR } \\
\text { Having PED as primary care physician versus having a GP }\end{array}$ & $0.62[0.40-0.96]$ & PED \\
\hline
\end{tabular}

This article is protected by copyright. All rights reserved 


\begin{tabular}{|l|l|l|l|l|l|}
\hline & & diagnosed 1995- \\
2011 & & & \\
\hline
\end{tabular}

AAT: anti-tissue transglutaminase antibodies; AAE: anti-endomysium antibodies; ADA: association for the diagnosis of diabetes FD: family doctors; PED: paediatricians; GP: general practitioner; rr: response rate; PR: prevalence ratio, ATB: antibiotics; CD: celiac disease GI: gastrointestinal ,y: years; dx: diagnosis DM diabetes mellitus, $\left({ }^{*}\right)<1$ favours FD/GP; >1 favours PEDs

This article is protected by copyright. All rights reserved 


\section{Fig 1. Summary of the study selection process}

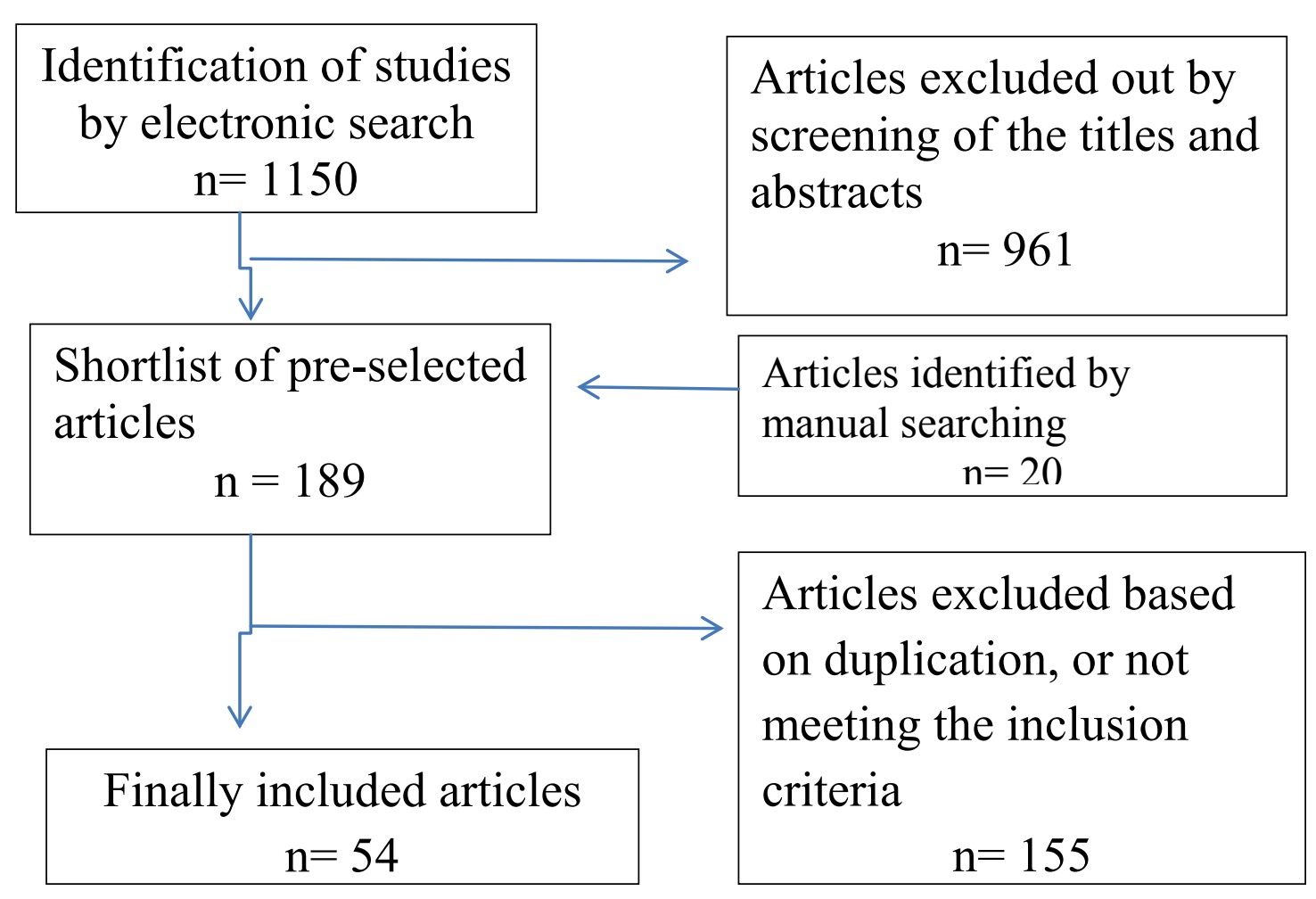

